\section{VIVIENDA PARA POBLACIÓN DESPLAZADA EN COLOMBIA. RECOMENDACIONES PARA LA POLÍTICA PÚBLICA Y EXIGIBILIDAD DEL DERECHO}

Carlos Alberto Torres Tovar ${ }^{1}$

Johanna Eloísa Vargas Moreno

\section{Resumen}

El presente artículo caracteriza la problemática de la vivienda y el hábitat para población en condición de desplazamiento forzado en Colombia, en el marco del contexto social y político de las tres últimas décadas, conflicto interno que ha obligado a 4.628.895 de colombianos a desplazarse y cuya manifestación se presenta de manera prioritaria en torno a 10 regiones y nueves ciudades. Identifica las particularidades de esta problemática en el marco general de los conflictos de la política pública de vivienda y hábitat y las consecuencias que acarrea para las familias de más bajos ingresos, así como, señala las limitaciones de respuesta de las políticas públicas al problema de la población desplazada. Presenta una sistematización de los principales

\section{HOUSING FOR DISPLACED POPULATION IN COLOMBIA. PUBLIC POLICY AND LAW ENFORCEMENT RECOMMENDATIONS}

\author{
Carlos Alberto Torres Tovar ${ }^{1}$ \\ Johanna Eloísa Vargas Moreno²
}

\section{Abstract}

This article characterizes the forced displacement population housing and habitat problem conditions in Colombia within the social and political context of the past three decades. Colombia's internal conflict has forced 4,628,895 Colombians to be displaced from their homes; this phenomenon is mainly experienced in 9 cities and 10 regions. It identifies the problem's peculiarities within the housing and habitat public policy's general conflicts and its consequences for low income families; as it highlights public policy limited response to population displacement. It presents a systematization of the main defining aspects of 
aspectos que definen esta problemática desde las perspectivas económica, política, social, cultural y territorial-regional. Contemplaalgunas alternativas para la solución a la necesidad del derecho a la vivienda y el hábitat para la población desplazada en Colombia. Termina el artículo haciendo una breve referencia al reciente pronunciamiento (enero 2009) de la Corte Constitucional a través del Auto de Seguimiento No 008 de 2009, que incluye varios aspectos a los que se refiere este artículo.

\section{PALABRAS CLAVES: NECESIDAD DE VIVIENDA, POBLACIÓN DESPLAZADA, POLÍTICAS DE DESPLAZAMIENTO, POLÍTICA DE VIVIENDA, DERECHOS.}

the problem from the economic, political, social, cultural, territorial and regional perspective. It includes possible alternative solutions to the need for a right of housing and habitat needs for displaced population in Colombia. The article ends with a brief reference to the recent ruling (January 2009) of the Constitutional Court through the Tracking ruling No. 008, 2009, which includes various aspects mentioned in this article.

\section{KEY WORDS: HOUSING NEED, DISPLACED POPULATION, DISPLACEMENT POLICY, HOUSING POLICY, RIGHTS.}

Fecha de Recepción: 25.03.09

Fecha de Aceptación: 02.07.09

1 Colombia. Arquitecto y Magister en Urbanismo. Profesor Asociado e Investigador. Escuela de Arquitectura y Urbanismo, Instituto de Investigaciones en Hábitat, Ciudad y Territorio. Universidad Nacional de Colombia. Editor Revista Bitácora Urbano Territorial. Correo electronico: catorrest@unal.edu.co

2 Colombia. Politóloga y Especialista en Ordenamiento Urbano Regional. Investigadora. Universidad Nacional de Colombia. Correo electronico: jevargasm@unal.edu.co
Received: 25.03 .09

Accepted: 02.07.09

1 Colombia. Architect and Master in Urban Planning. Associate Professor and Researcher. School of Architecture and Urban Planning, Research Institute in Habitat, City and Territory. Universidad Nacional de Colombia, Editor “Bitacora Urbano Territorial" Journal. Email: catorrest@unal.edu.co

2 Colombia. Political Scientist and Regional Urban Plaining Specialist, Researcher. Universidad Nacional de Colombia Email: jevargasm@unal.edu.co 
"En las ciudades colombianas la brecha sigue creciendo y el vacio insalvable entre los que tienen $y$ los que no, es cada vez más vertiginoso. Las diferencias se agudizan, pero el contacto permanece porque habitamos un mismo territorio. La población desplazada llega a espacios ya ocupados, ya intervenidos y transformados, donde el viscoso humo contaminante de la lucha por la sobrevivencia los recibe para ocultarlos, para esconderlos, pero también para exponerlos al sacrificio de ser pobres en lugares donde la eliminación de la pobreza se sigue dando por la vía de su eliminación física".

Los autores

\section{Introducción ${ }^{3}$}

Existe un límite entre lo deseable y lo posible y allí se encuentra la política. Acceder e incidir en la definición de lo que es realizable con el fin de alcanzar la dignificación de la condición humana y con ella la democratización de sus relaciones, es una tarea inaplazable e intrínseca al quehacer del conjunto social. Sin embargo, las agudas diferencias, exclusiones y violencias en las cuales se ha definido el porvenir de lo posible para la

3 El presente documento fue elaborado en el marco de la investigación para el "Proceso Nacional de Verificación a la Sentencia T-025 de 2004", Mesa de expertos - derecho a la vivienda, en el cual se realizó el análisis, las reflexiones y las recomendaciones sobre la exigibilidad del derecho a la vivienda para la población desplazada en Colombia (TORRES, 2008).
"In colombian cities the gap keeps growing; and void between the ones who have and those who have not is even more vertiginous, differences have become more evident; though still in contact with one another as we live in the same territory. The displaced population arrives to spaces already occupied, intervened and transformed where polluted fumes welcome them within the poor's survival struggle to hide, conceal the deprived ones, though also to expose them to the sacrifice of poverty life, in places where poverty eradication still is through the physical one".

The authors

\section{Introduction $^{3}$}

Politics lay between the thin line of that desirable and possible. To define what is achievable to dignify human condition, and the democratization of its relationship is an urgent task intrinsic to society itself. Notwithstanding the acute differences, exclusions and violations in which Colombia's society possible future has been defined that

3 This article was part of the "Proceso Nacional de Verificación a la Sentencia T-025 de 2004"( National Process Verification of Ruling $\mathrm{T}-025,2004)$ research, Experts' Table - right of housing, in which the analysis, reflex ions and recommendations were made related to the right of housing demand by displaced population in Colombia (TORRES, 2008). 
sociedad colombiana, han convertido la tarea de búsqueda de la democracia, que es propia a cada integrante de la sociedad, en un reto heroico y hasta utópico.

En este sentido, plantearse la apuesta por encontrar alternativas posibles, susceptibles de convertirse en política pública, en relación a las cuestiones de la vivienda y el hábitat, en un país donde el Estado ha reducido las alternativas de opciones distintas a las mediaciones o determinaciones del mercado, no ha sido fácil. Sin embargo, ante las limitaciones prima la importancia de estas búsquedas, las cuales no deben cesar en tanto la vida y el derecho a vivirla plenamente no sean una realidad para toda la población que habita el territorio nacional.

Y es así, buscando, que se ha encontrado que en el país el proceso de consolidación de centros urbanos y regionales, durante los últimos 50 años, ha carecido de rutas orientadoras adecuadas, de claros procesos de planeación y de la construcción de políticas públicas acordes con las dimensiones que han tomado los procesos urbanos y los diferentes aspectos que la integran, entre los cuales sobresale el desplazamiento forzado de población a causa del conflicto armado interno ${ }^{4}$.

4 El acumulado de población desplazada en Colombia en el periodo comprendido entre los años 1985 - 2008 es de 4.628 .895 de colombianos según la Consultoría para los Derechos Humanos y el Desplazamiento -CODHES- (CODHES, 2009), lo que equivale a que por cada 10 colombianos uno ha sido desplazado de manera forzada en los últimos 25 años. has made democracy search task, and it is part of each member of society responsibility, into a heroic even utopian deed.

It has not been easy to set goals to find possible, feasible alternatives that could become housing and habitat public policies in a country where the State has reduced options' alternatives different to the ones given by the market and evaluations from this perspective; though within the existing limitations is more important to keep searching them as long as life and the right to fully live it becomes a reality for every single person who lives in Colombia.

Through this search urban and regional centers have consolidated the last 50 years. It lacks proper guidelines that include suitable urban planning and public policies construction that agrees with the urban growing process and the different aspects that are part of it that in Colombia's reality outstands the forced population displacement due to the internal armed conflict ${ }^{4}$.

4 The total number of displaced population in Colombia between the years 1985 - 2008 is 4.628 .895 according to Human Rights and Displacement Consultancy (Consultoría para los Derechos Humanos y el Desplazamiento -CODHES- (CODHES, 2009)), which means for every 10 Colombians 1 has been forcibly displaced in the last 25 years. 
La agudización del conflicto durante las últimas dos décadas ha transformado la dinámica de crecimiento de las ciudades colombianas. De procesos migratorios provocados por los cambios en la producción agrícola y pecuaria bajo formas atrasadas de producción que han desembocado en la concentración del desarrollo económico en las ciudades, y el encuentro de una serie de garantías para el mejoramiento de las condiciones de vida; la dinámica urbana nacional ha transitado hacia el poblamiento desbordante a causa del desplazamiento forzado que se produce como consecuencia inmediata a hechos de violencia ocurridos en los lugares de origen de las personas que se movilizan en la casi totalidad del territorio colombiano.

Esta problemática se suma al de por sí conflictivo desarrollo urbano que ante la ausencia de un marco de política pública capaz de prever su adecuado crecimiento, ha mantenido la constante histórica del crecimiento dual, por una parte la configuración formal y planificada del territorio urbano y de otra la informalidad como forma de construcción de ciudad y sociedad manifiesta en la ocupación de hecho de los territorios. Dicha ausencia de políticas se ha convertido, en sí misma, en una de las causas de mayor peso del conflicto urbano, al permitir por anomia, la permanencia y desarrollo de problemáticas que se van acumulando y mutando entre sí para adaptarse a nuevos tiempos y a nuevos problemas.
The conflict's aggravation during the last two decades has transformed Colombian cities growing dynamic. The migration processes due to farming and livestock production changes, which uses out dated production methods that have led economical development concentration in cities as well as a number of the life improvement guaranties. The national urban dynamic has moved to cities' resulting in over population caused by forced displacement immediate consequence to armed conflict in the people's place of origin that produces moving flows in almost every part of Colombian territory.

This problem adds up to the natural urban growing development dilemma caused by inappropriate public policies framework capable of foreseeing its adequate growing. This has kept the historical dual growing constant; on one hand the urban territory formal planning configuration and on the other the informal one as city's construction form that portrays in squatting. This lack of policies has become, by itself, one of the urban conflict main reasons, as it allows by anomy the problem existence, continuance and development that keeps adding and mutating to new realities and problems. 
La población desplazada llega a las ciudades ha "rebuscarse" la vida, afrontando, sin más herramientas que sus propias manos, todos los conflictos urbanos derivados de nuestra particular formación social. La vivienda se convierte en una de las primeras búsquedas, para la cual existen pocas e inadecuadas respuestas, produciendo la pauperización de las condiciones habitacionales de los "nuevos vecinos", a la vez que se complejiza la dinámica global del ordenamiento y el planeamiento urbano.

Así las cosas, vale la pena dar mejores y más adecuadas respuestas a esta situación, para lo cual se debe recurrir a los resultados de procesos de investigación y de ejercicios políticos concretos, relacionados, en este caso, con la problemática de la vivienda y el hábitat en Colombia ${ }^{5}$ y con los derechos de la población que ha sido desplazada.

Dichos procesos, desarrollos y resultados serán abordados en el presente artículo, a lo largo del cual se encontrará la descripción de los aspectos más relevantes que constituyen tanto la problemática como las alternativas para el restablecimiento del derecho a la vivienda para la población desplazada.

5 Según los resultados del Censo General del 2005 (DANE), el 36,21\% de los hogares del país presentó necesidades habitacionales (3.955.776); el déficit cuantitativo, cuya atención demanda la generación de unidades habitacionales nuevas, asciende a 1.351.366 hogares y corresponde principalmente (34.16\%) al tipo cohabitación (hogares que comparten la vivienda con otros hogares). El déficit cualitativo asciende a 2.604 .411 (65.84\%).
The displaced population arrives to cities to "research" life by their own means. All urban conflicts derived from this particular social formation in our country. Housing is one of the first thing they tackle and not many adequate answers arise, producing greater poverty in the existing housing conditions to the "new neighbors" as well as complicates the global organization dynamic and urban planning.

It is better to provide adequate answers to the problem that come out of proper researches on the subject and real political exercise that deal with the problem, in this case housing and habitat in Colombia $a^{5}$ and the rights of the displaced population.

These processes, development and results will be covered in this article in which the relevant aspect of this problem will be described as well as their right reinstatement alternatives for the displaced population. It ends naming

5 According to the 2005 Census result (DANE), 36,21\% of Colombia's home showed housing needs (3.955.776); the quantitative deficit that demands new housing unit construction is of 1.351 .366 homes which is $(34.16 \%)$ of cohabitation type (shared housing with other families). The quality deficit is 2.604 .411 (65.84\%). 
Finaliza con la enunciación de aquellos elementos que han sido reconocidos por la Corte Constitucional Colombiana, como relevantes en el actual proceso de superación del Estado de Cosas Inconstitucional -ECI-, declarado en la Sentencia T- 025 de $2004^{6}$ y ratificado en el Auto $\mathrm{N}^{\circ} 008$ de $2009^{7}$.

\section{Contexto y problemática}

Dentro de la gran cantidad de derechos que son violados cotidianamente a la población desplazada, el de la vivienda resulta de actual importancia, ya que otro tipo de derechos que demandan igual restitución han venido siendo atendidos a través de los espacios y equipamiento existentes como lo son

6 Sentencia de la Corte Constitucional colombiana que estableció una base para el reconocimiento y la realización efectiva de los derechos de la población desplazada. Esta se profiere después de haber declarado la gravedad de la situación de esta población, reconociendo la existencia de un Estado de Cosas Inconstitucional -ECl-, indicando el desconocimiento generalizado de los derechos consagrados en la Ley y en los principios rectores sobre desplazamiento forzado interno consagrados por las Naciones Unidas en 1998.

7 El 26 de enero de 2009, mediante este Auto, la Corte Constitucional Colombiana ratificó la persistencia del ECI declarado mediante sentencia T-025 de 2004 en relación a la población desplazada. Este Auto conmina al Estado a garantizar el goce efectivo de los derechos de la población desplazada en un tiempo delimitado mediante el mejoramiento de la capacidad institucional; garantizando la idoneidad de las políticas públicas para lograr el goce efectivo de los derechos y la superación del ECI (incluye el replanteamiento de la Política de Vivienda para la población desplazada); y la superación de vacíos protuberantes en la formulación e implementación de las políticas públicas. the elements that have been recognized by the Colombian Constitutional Court as relevant to the current state of things overcoming process -ECI- court ruling T-025 20046 ratify by ruling sentence $\mathrm{N}^{\circ} 008$ de $2009^{7}$.

\section{Problem and its context}

The displace population suffers many rights violation in daily terms, and the housing rights become key as other rights have been address through the existing rights to education and health that the displaced population do have

6 The Colombian Constitutional Court ruling that acknowledge the displaced population rights. This was addressed after declaring this people grave situation in an unconstitutional state -ECl-, pointing out the general ignorance to the Law that gave them its Rights as well as displacement ruling principles of the 1998 United Nations charter.

7 January 26th 2009, Colombian Constitutional Ruling ratified ECI declared in ruling T-025 de 2004 related to displaced population. This ruling warns the State to effectively guarantee the displaced populations Rights within institucional capacity improvement to guarantee the public policies suitability to give them their effective rights' exercise. ECI (includes reformulation of Housing Policies for displaced population); and to fill the gaps in public policies formulation and implementation. 
y colombianas que supera el grupo de la población desplazada existente.

Partiendo entonces de la importancia de la reflexión y la necesidad de la construcción de propuestas frente al déficit acumulado en el tema de vivienda para la población desplazada, se propone el desarrollo analítico de aspectos relevantes para la comprensión de las dimensiones, el contexto y los alcances de las alternativas.

El primer aspecto corresponde al contexto político y social colombiano, el segundo al desplazamiento en el marco de dicho contexto de conflicto, el tercer aspecto plantea una breve reflexión sobre los principales problemas de la vivienda y el hábitat en América Latina y Colombia, el cuarto está referido a lo que ha sido la política pública de vivienda en Colombia, como quinto elemento se caracterizan los principales componentes de las actuales políticas de vivienda y hábitat, y por último sobre la base de la caracterización construida se ubican algunos rasgos de la situación de vivienda de la población desplazada en Colombia.

\section{EL DESPLAZAMIENTO FORZADO EN EL CONTEXTO POLÍTICO Y SOCIAL COLOMBIANO}

Señalar que en Colombia asistimos a una crisis estructural no es nada nuevo, pero es siempre necesario recordarlo. La configuración histórica de las problemáticas actuales debe estar presente en
Starting from the construction need analysis proposed by the displaced population accumulated housing deficit; an analytical development is proposed to understand the relevant aspects dimension, its context and possible alternatives reach.

The first aspects relates to Colombian political and social context, the second one to displacement due to the conflict context framework, the third one relates to the main housing and habitat problems in Latin America and Colombia, the fourth one refers to Colombia's housing public policies up to now, fifth one deals with the current housing and habitat policies main components characteristics; and the last one based on the built characterization some of the displaced population situation features in Colombia.

\section{FORCED DISPLACEMENT IN COLOMBIA'S POLITICAL AND SOCIAL CONTEXT}

Colombia's structural crisis is nothing new, though it is always necessary to remember it. The current problems historical configuration must be in each and every attempt to characterize the moment, and even more if we are trying to look for alternatives and 
todos y cada uno de los intentos por caracterizar el momento y más aún cuando se trata de buscar alternativas y soluciones a uno $u$ otro aspecto de los que integran y definen dicha crisis. Parafraseando a Emilio Pradilla Cobos,

"(...) Los grandes problemas regionales y urbanos generados por el despliegue del capitalismo en Colombia y la urbanización generalizada (...) no fueron resueltos por el patrón de acumulación de capital con intervencionismo estatal imperante en la posguerra. La crisis del modelo, la abrupta aplicación del ajuste estructural neoliberal desde 1991 -partero de otro régimen de acumulación- y la inserción asimétrica y subordinada del país en la globalización han generado nuevas contradicciones territoriales que se añaden a las viejas"s.

Se parte del análisis del conflicto social y político colombiano como eje estructural de la problemática vivida por la población, perspectiva que no puede ser obviada en la búsqueda de soluciones. Su revisión debe permitir salir del encasillamiento de un conflicto que tiene a los bandos definidos en el campo exclusivo del enfrentamiento armado, para saltar a una lectura que integre los intereses económicos y políticos promovidos por actores no necesariamente armados pero sí con la capacidad de orientación y definición de estrategias de ocupación y desalojo de tierras, dentro de los cuales sobresalen en el último periodo como

Pradilla, Emilio. 2002. Pág. 1. solutions in one or all the aspects that are involved and define the crisis. Paraphrasing Emilio Pradilla Cobos:

“(...) The great regional and urban problems originated by capitalism policies in Colombia and generalized urbanization (...) were not solved by the capital accumulation pattern with the prevailing post war state interventionism. The model crisis, the abrupt neo liberal structural adjustments since 1991 -another accumulation regime midwife- and the country's asymmetric and subordinated insertion in globalization has generated new territorial contradictions that add to the old ones." 8

The starting points is Colombia social and political conflict analysis as the structural axis to the housing problem lived by the population, perspectives that can not be overlooked when solutions are searched. Its revision must allow getting out of the conflict's pigeon hole that has both sides in the exclusive armed conflict arena definition to jump into a reading that includes economic and political interests promoted by not necessarily armed actors, though with guiding; land occupation and eviction strategies definition capacities, among which

8 Pradilla, Emilio. 2002. Pág. 1. 
actores protagónicos las multinacionales de recursos naturales y biocombustibles y las mafias del narcotráfico amparadas por amplios sectores políticos ubicados en las instituciones del Estado y en empleados del gobierno nacional, regional y local.

En este marco encontramos que el gobierno de ÁlvaroUribe Vélez halogrado mayores compromisos de los Estados Unidos con el financiamiento y respaldo político de la estrategia guerrerista de Estado concretados en el Plan Colombia, Plan Patriota y Plan Puebla Panamá, referentes claros de la intervención de las multinacionales de la guerra en los países del sur del continente, encabezados por Colombia. En este contexto la problemática del desplazamiento forzoso ha ampliado su magnitud, su complejidad y el nivel de ocupación de los territorios urbanos.

Aunque el fenómeno tiene como origen el conflicto político que viene desgarrando nuestro país, en las ciudades se traduce en una problemática social y económica, ya que la realidad urbana es excluyente y limita la construcción de tejido social, la vinculación laboral, entre otras, quedando para muchos la única opción de la miseria y en algunos casos la indigencia. natural resources and bio-fuels multinational outstands as main protagonists and the narcotrafficking mafias shelter by broad political sectors in the State institutions and regional, national and local government officials.

Within this framework Alvaro Uribe Velez government has achieved better state guerilla strategies financial and political support commitments with the US in the "Plan Colombia", "Plan Patriota", "Plan Puebla Panama" that clearly shows multinational intervention in the war of the southern countries of the continent, led by Colombia. Within this framework the forced displacement problem has broaden its magnitude, complexity and urban territory occupation percentage.

Although the problem derives from the political conflict that is tearing out our country, it translates into cities as an economic and social problem as urban reality excludes and limits the social network construction among others labor contacts, giving no choice but misery and in some cases even indigence. 
Aproximadamente el $8.93 \%{ }^{9}$ del total de la población colombiana llega a las ciudades forzada a encontrar un lugar donde proteger su vida y las de sus familiares, después de ser expulsados por amenazas, muerte y/o reclutamiento de familiares (en su mayoría hombres) y acusaciones, entre otras circunstancias.

"Las situaciones que motivan la salida en orden de frecuencia: Las amenazas directas (82.2\%) relacionadas con reclutamiento forzado del jefe del hogar y/o los hijos e hijas mayores de $11-12$ años de edad; acusaciones de ser colaboradores del ejército o del grupo armado ilegal contrario que haya pasado antes por sus tierras; por resistirse, o no poder cumplir con la cuota extorsiva (denominada "vacuna") en dinero o recursos de producción; por desaparición forzada del jefe del hogar, de hijos o de otro familiar cercano; por el asesinato de vecinos; el temor a los enfrentamientos y el despeje de la zona por uno de los actores armado. Las amenazas indirectas (27.8\%), las cuales son relacionadas por las personas con: combates, situaciones de tensión, alteraciones del orden público, miedo generalizado, masacres, asesinatos y desapariciones en lugares cercanos a su lugar de vivienda."10

9 Siguiendo la cifra entregada por la Consultoría para los Derechos Humanos y el Desplazamiento -CODHES- en el documento de la Comisión de Seguimiento a la Política Pública sobre Desplazamiento Forzado. Sentencia T - 025 - Primer Informe: Desplazamiento Forzado y Políticas Públicas de diciembre de 2006.

10 MONTEIR0, Teresinha et al. 2007. Pág. 59-60.
Approximately $8.93 \%$ of the total displaced population in Colombia comes to the city forced to find a safe place to protect their lives and family after being expelled by treats, death and/or family member recruitment (especially men), accusations among other circumstances.

"The reasons that motivates displacement in order of frequency: Direct threats (82.2\%) related to recruitment - Head of household and/or children older than 11-12 years old forced recruitment; army or the illegal armed group collaboration accusations that has passed before through their land; resisting, because they can not meet with the extortion fee (called "vaccine") either money or production resources; by head of household, children or other close family member forced disappearance; neighbors murder; fear of fighting and the area clearance by one of the armed sides. Indirect threats (27.8\%) which are related to people with: Combat, tense situations, public order disturbance, massacres, murders and disappearances in near by places." 10

9 Data provided by Consultoría para los Derechos Humanos y el Desplazamiento -CODHES- in Follow up Commission Document of the Forced Displacement Public Policies follow up. Ruling T - 025 - First Report: Forced Displacement and Public Policies December 2006.

10 MONTEIRO, Teresinha et al. 2007. Pág. 59-60. 
Ante la crisis han sido muchos los llamados de atención de orden nacional e internacional que se han hecho durante la última década a partir de la promulgación de la Ley 387 de $1997^{11}$, en relación con la responsabilidad del Estado frente a la población desplazada y en general frente al fenómeno del desplazamiento forzado. Sin embargo, las raíces estructurales del conflicto atadas a los ya mencionados procesos de explotación e inversión económica han sido profundizadas y orientadas como única posibilidad para el desarrollo social.

A esto se suma la búsqueda de la paz por la vía de la guerra como estrategia de Estado, que ha devenido en el aumento de recursos de todo tipo para garantizar el fortalecimiento de los dispositivos de control y choque (inteligencia, aumento del pie de fuerza, tecnificación de la confrontación, entre otros), facilitando el ordenamiento y ocupación del territorio en función de los intereses impulsados por el modelo. La polarización de los actores enfrentados y sus repercusiones en el conjunto social, en términos de su apoyo a uno u otro actor, han limitado y

11 Ley por la cual se adoptan medidas para la prevención del desplazamiento forzado; la atención, protección, consolidación y esta estabilización socioeconómica de los desplazados internos por la violencia en la República de Colombia. Esta ha sido reglamentada parcialmente por los Decretos Nacionales 951, 2562 y 2569 de 2001.
There has been many attention calls done during the crisis the last decade either by the national or international order after ruling Law 387 de $1997^{11}$ related to displaced population State responsibility and the forced displacement phenomena in general. Nonetheless the conflict structural roots linked to the above mentioned, economic investments and exploitation processes that have been guided and deepened as the only possibility for social development.

This adds up to the State strategy to search peace through war that has translated into increasing all type of resources to guarantee the control and clash mechanisms strengthening (intelligence, increasing number of soldiers, technology introduction in the confrontation among other elements) helping territory occupation and management depending on the model's promoted interests. The polarization of the confronting actors involved and its repercussion in the whole Colombian society in terms of their support to one side or the other which has limited and

11 Law that deal with adoption measures to prevent forced displacement; socio economic attention, protection, consolidation and stabilization for the internal displaced by violence in Colombia. This has been mainly partially ruled by the National Decreet 951, 2562 y 25692001. 


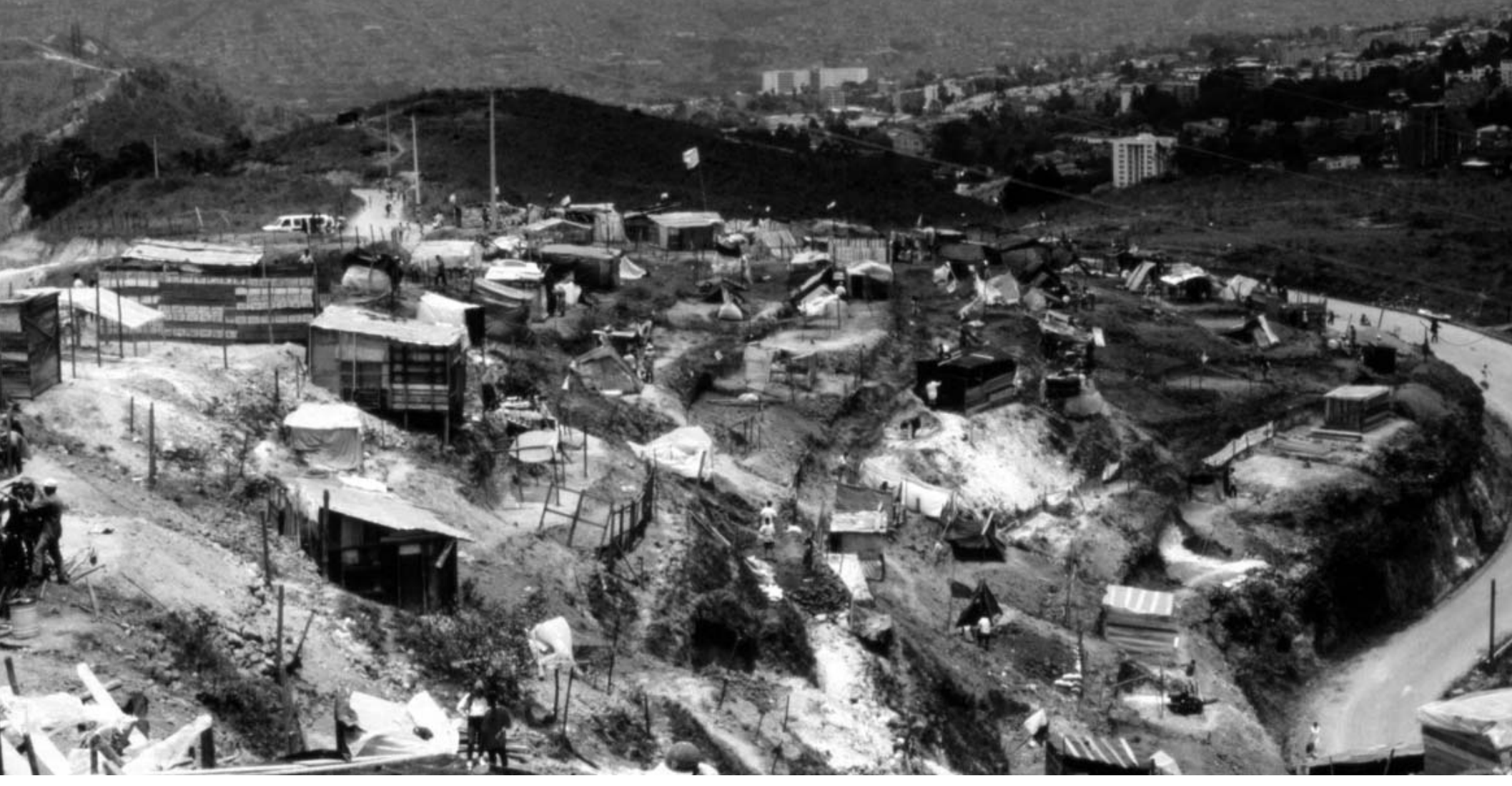

Población desplazada invade en Medellín. Un grupo de desplazados del Uraba Antioqueño conforman, mediante invasión en un terreno público en la ciudad de Medellín, un barrio en reclamo a su derecho a una vivienda digna en el año 1998. Dos días después de tomada esta imagen fueron desalojados por la fuerza pública.

Fuente de la Fotografía: Carlos Torres Tovar, 1998.

Displaced population invades Medellin. Displaced population group from Uraba Antiqueño which squatted public land in Medellin City. A neighborhood claiming its right to descent housing in 1998. Two days after this picture was taken, they were evicted by public force.

Photography source: Carlos Torres Tovar, 1998. 
desconocido otras opciones que conduzcan a la superación del conflicto.

“(...) por diversos motivos, no existe la garantía de que el proceso de diálogo va a conducir a la superación definitiva del paramilitarismo, y a cambio se tiene la certeza de que se va a producir una operación de impunidad a gran escala, sin garantías para obtener la verdad que puedan conducir al desmonte de estructuras políticas y económicas del paramilitarismo, ni procesos de reparación integral que restituyan integralmente a las víctimas." ${ }^{\prime 2}$

En este contexto, las alternativas al desplazamiento deben reconocer la necesidad de confrontar las orientaciones generales de la política con el fin de impulsar cambios sustanciales que desde nuevas orientaciones $-\mathrm{y}$ no solamente a través de "ayudas asistenciales"- permitan condiciones donde la búsqueda del desarrollo y la productividad beneficien a toda la población.

\section{CARACTERÍSTICAS GEOPOLÍTICAS DEL DESPLAZAMIENTO EN COLOMBIA}

El eje central de los procesos de reforma política, económica y social propiciados por el modelo neoliberal, ha sido el reordenamiento del territorio en un contexto en el cual las disputas por éste han sido la constante. La inexistencia de una Ley

12 ROMERO, Marco. 2006. pág. 33. refused to acknowledge other possible options to overcome the conflict.

"(...) for different reasons, there is not guarantee that the dialogue process is going to lead to overcome paramilitary groups on the other hand it is certain a great scale impunity operation will be produced with no guarantee that truth will be said in order to dismantle parliamentary political andeconomic structures nor any integral reparation process that would fully restore their loses to the victims" 12

The displacement alternatives in this context must recognize the need to address the policies general guidance to push substantial changes from a different point of view than the ones taken up to now, and not only through "assistant aid", that allows conditions to develop and productivity that benefits the whole population.

\section{DISPLACEMENT'S GEOPOLITICAL CHARACTERISTICS IN COLOMBIA}

The political, economic and social reforms processes central axis foster by the neo liberal model has been the territory reordering where the disputes for the territory have been

12 ROMERO, Marco. 2006. p. 33. 
Orgánica de Ordenamiento Territorial -LOOT ${ }^{13}$ ante la negligencia estatal y la falta de presión social para que ésta se realice, son hechos que han permitido que se mantenga el privilegio del mercado y los agentes del sector privado como ordenadores.

En este sentido, la anarquía y la lucha constante por un lugar donde realizar la vida a partir de condiciones materiales desfavorables, sin ninguna garantía ni protección del Estado se convirtieron en la forma a través de la cual se sostienen en la cotidianidad órdenes establecidos o determinados por dinámicas -económicas, culturales y políticas- que poco o nada tienen que ver con los órdenes político - administrativos establecidos legalmente.

Es así como, por ejemplo, los departamentos ${ }^{14}$ han venido desdibujándose como entidades administrativas de ordenamiento territorial con capacidad de incidir en las dinámicas de la población, la cual se mueve a través de lógicas

13 El Artículo 288 de la Constitución Política de Colombia de 1991 establece que se deberá formular una " (...) ley orgánica de ordenamiento territorial (que) establecerá la distribución de competencias entre la Nación y las entidades territoriales. Las competencias atribuidas a los distintos niveles territoriales serán ejercidas conforme a los principios de coordinación, concurrencia y subsidiariedad en los términos que establezca la Ley". Esta Ley no ha sido promulgada aún.

14 Son 32 subdivisiones político administrativas con las que cuenta Colombia desde la Constitución Política de 1991. a constant. The inexistence of a Territorial Regulation Organic Law LOOT ${ }^{13}$ is due to the state's negligence and the lack of social pressure to push the law. This has allowed that the market and private sector agents regulate it.

Anarchy and permanent struggle to live in unfavorable conditions, with no protection guarantee from the State becomes the way everyday life regulation originated or determined by political, economic, cultural and social dynamics that hardly have anything to do with the political administrative order legally established.

For example the departments ${ }^{14}$ have been blurring as territorial regulation administrative identities and their competence to make an impact in the population's dynamics that moves through municipal and/

13 Article 288 of the Political Constitution of Colombia 1991 establishes that it must be formulated a " $(. .$.$) territorial regulation organic law$ that will distribute competences between the Nation and territorial entities. The distributed competences among the different territorial levels should be exercised in conformity to the coordination, concurrence and subsidiary principles according to the Law". This law has not been passed yet.

14 There are 32 administrative political subdivisions in Colombia since 1991 Political Constitution. 
municipales y/o regionales principalmente ${ }^{15}$. Las regiones que no cuentan con una estructura legal de respaldo, son hoy -como antes- los escenarios en los que se concreta la dinámica de reordenamiento poblacional determinada por el conflicto.

"(...) el examen regional de la relación entre conflicto y desplazamiento desvirtúa la tesis oficial, según la cual la mayor presencia militar asegura, per se, mayores condiciones de seguridad a los pobladores. Los municipios de mayores tasas de desplazamiento están localizados precisamente en aquellas regiones convertidas en teatro de operaciones, en las cuales se entrecruzan antiguas y nuevas tácticas de confrontación propias de la guerra irregular, cuyo resultado es el surgimiento de nuevas causas y modalidades de desplazamiento forzado, y el deterioro progresivo de las garantías de la población civil." 16

En este sentido vale la pena observar algunos indicadores de la caracterización demográfica del desplazamiento para develar el proceso en términos

15 La imposibilidad de configurar un Estado fuerte en Colombia -y en otros países de América Latina- pasa fundamentalmente por la debilidad de su ordenamiento territorial, el cual para nuestro caso no ha logrado resolver la tención entre el centralismo y el federalismo, desconociendo la tendencia histórica a la regionalización como forma privilegiada de organización de la vida de los habitantes en cada uno de los puntos que integran el complejo territorio natural. Desde las configuraciones biofísicas hasta los procesos de organización política se han constituido en relación a la dinámica regional y en menos ocasiones en relación a los límites político - administrativos impuestos por la norma como entidades territoriales.

16 ROMERO, Marco. 2006. Pág. 23 or regional $\operatorname{logic} 15$. The regions that do not have legal structure to back them up; are now, as they were before; where population re-ordering dynamic takes place determined by the conflict.

“(...) the relationship conflict and displacement regional test invalidates the official thesis that says that more troops present, per se guarantees better safety conditions for the population. The municipalities with the largest displaced population are in fact the ones that hold the military operations where interweave old and new confrontation tactics characteristical of this kind or guerrilla wars which results in new causes of forced displacement and deterioration of the civil population guarantees." 16

It is important to look at the demographic displacement characterization indexes to

15 The incapacity to built a strong State in Colombia - and in other countries in Latin America- it explains by the weaknesses in their territorial regulation, in our case it has not been able to solve the tension between centralized and federal structure, overlooking the regional historical structure as the way they have organized their lives, its inhabitants in each of the complex natural territories that make Colombia. From the bio-physical to the political organization policies has been organized around a regional structure and in rare cases in relation to political, administrative borders - imposed by the norm as territorial entities.

16 ROMERO, Marco. 2006. p. 23. 
MAPA Nº. 1. DISTRIBUCIÓN TERRITORIAL DE LA POBLACIÓN. EXPULSIÓN Y RECEPCIÓN 2000 - 2004.

MAP NN. 1. POPULATION TERRITORIAL DISTRIBUTION. EXPULSION AND RECEPTION 2000 - 2004.

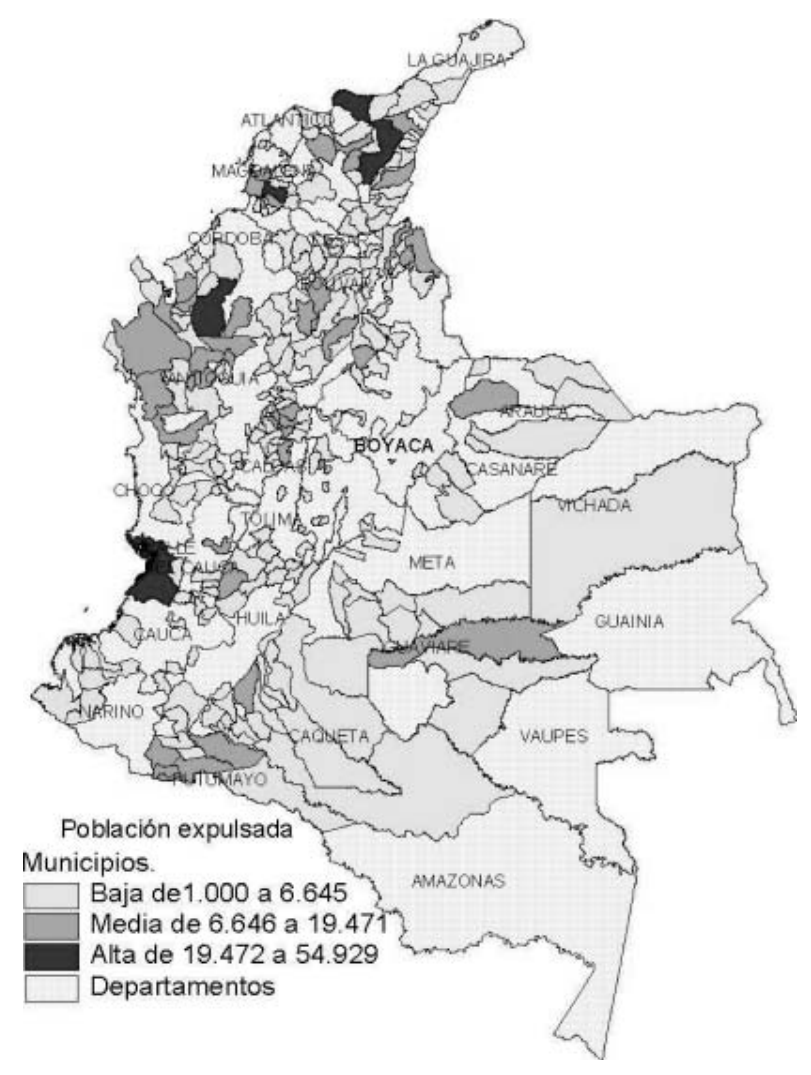

Fuente: Ruiz, Nubia (2008). 
de su ubicación territorial y las configuraciones regionales que deben ser observadas para la búsqueda de cualquier tipo de alternativa.

\footnotetext{
"La expulsión de población es un fenómeno presente en todos los municipios del país; los 1.098 expulsan población, mientras que la recepción se hace en 80,6\% (885) de los municipios. ${ }^{17}$ A esta cifra se suma la arrojada por el Índice de Impacto demográfico, “... concebido como un valor que sintetiza la afección en positivo o negativo, de acuerdo con la ganancia o pérdida de población que tienen las estructuras demográficas y los territorios." ${ }^{18}$ Ello se observa en el Mapa $\mathrm{N}^{\mathrm{o}}$ 1:
}

La mayor expulsión se concentra en el norte y sur occidente del país, mientras la recepción aunque se mantiene en las zonas nororiental y sur - occidental también se ubica en un alto porcentaje en la ciudad de Bogotá. En este proceso de desplazamiento se pueden ubicar tres momentos o estadios. Uno el inmediato realizado a lugares cercanos, el segundo hacia municipios cercanos o cabeceras municipales y el tercero hacia las grandes ciudades. En esta lógica se encontró que para el periodo 2000 2004 el 60\% de la población se desplazó al interior de una misma región.

Las regiones emergentes son consideradas como aquellas al interior de las cuales se presentan con mayor fuerza los flujos y pasos por las tres etapas de reveal the process in territorial displacement and regional configurations search for any kind of alternative to solve this problem.

"The population exile is an existing phenomenon in every single municipality in Colombia. 1,098 municipalities do it and only $80.6 \%$ (885) of them receives the population. ${ }^{17}$ It adds up to this percentage the demographic impact index, that shows the different territories and demographic structures gain or loss of population." 18 As it shows in the map.

The concentration of war exile is mainly in the North and South East of the country, on the other hand reception keeps within North West and South, West also has a percentage mostly in the city of Bogota. In this displacement process 3 stages can be distinguished. First, the immediate one or the near-by places done, the second one to the near by municipalities or to the head municipalities and the third one to big cities. This logic showed that between 2000-2004 60\% of the population displaced to the inlands of the same region.

The emerging regions are considered those ones inland where the 3 stages are detected
17 RUIZ, Nubia. 2008. Pág. 19.
18 Ibíd. Pág. 15.
17 RUIZ, Nubia. 2008. p 19.
18 Ibíd. pág. 15. 
movimiento del desplazamiento. Dichas regiones son: Urabá, Magdalena medio, Andina central, Montes de María, Piedemonte llanero, frontera con Venezuela, zona bananera, Pacífico Central y la zona de frontera con el Ecuador.

Esta dinámica regional evidencia que al interior de dichas regiones el desplazamiento se realiza hacia las cabeceras municipales o hacia las principales ciudades, teniendo para la región Andina a Bogotá como la mayor receptora, con el $26.5 \%$ del total; en la región - zona bananera aparece Santa Marta con el 43\%; en Montes de María aparece Sincelejo como el lugar adonde llega mayor población con un 39\%; en la región de frontera con el Ecuador la ciudad de Pasto es la que más población recibe con un 13.3\%; en la frontera con Venezuela es la ciudad de Cúcuta con el 36.1\%; en la región del Magdalena medio es Bucaramanga con el 11.9\%; para la región del Pacífico central aparece Medellín como la principal ciudad receptora con el 25\%; en el Pacifico Sur es Cali con el 34.6\%; en el Piedemonte la ciudad que más población recibe es Villavicencio con un 38.5\% y, por último, en la región de Urabá vuelve a ser Medellín la ciudad que más recibe con un 30.84\%.

Esta información permite ubicar 9 ciudades prioritarias a través de las cuales puede ejecutarse la política social para el restablecimiento de derechos de la población desplazada, así como las apuestas por construir redes de desarrollo que articulen and the greatest displacement flow shows. These regions are: Uraba, middle Magdalena, Central Andean, Hills of María, flat Piedemonte, Venezuelan border, banana Zone, Central Pacific and Ecuadorian border.

This regional dynamics shows that these regions inland displacement moves towards municipality head or to Colombia's main cities. Andean Region to Bogota with the largest percentage of the total in the region with 26.5\% - banana zone shows Santa Marta with 43\%; in Hills of Maria, Sincelejo where most of the population goes with 39\%; Ecuadorian border region, Pasto gets most of the population with a $13.3 \%$; Venezuelan border Cucuta with 36.1\%. Middle Magdalena, Bucaramanga with $11.9 \%$, central Pacific region Medellin as the main city with 25\%, in South Pacific, Cali with $34.6 \%$. Piedemonte gets most of it displaced population in Villavicencio with $38.5 \%$ and last Uraba mostly attracts them to Medellin with a $30.84 \%$.

This information shows 9 cities that can be taken as the social policies target to reestablish the displaced population's rights as well as to build development networks that 
procesos productivos hacia el interior del país con verdaderos impactos regionales.

Otro aspecto a resaltar que arroja el análisis de ubicación territorial y movimiento demográfico de la población desplazada es el relacionado con las causas del conflicto, dentro de las cuales sobresale el desplazamiento por acumulación de tierra, lo cual corresponde directamente con los elementos esbozados al inicio del documento, en relación a las motivaciones de tipo económico por reorganizar el territorio.

Aunque el aumento de la concentración de tierras es un hecho de por sí violento, la distinción que aquí se hace permite evidenciar que la mayoría de regiones -siete de diez- presentan como causa principal del desplazamiento dicha concentración de la tierra. Es entonces evidente cómo el proceso de contrarreforma avanza con consecuencias nefastas para la población que es expropiada de sus bienes, los cuales en muchos casos heredaron durante generaciones, para pasar a ser forasteros en su propia tierra.

La integralidad del conflicto es un hecho cada vez más evidente en las intervenciones gubernamentales. Sin embargo, existen en las dinámicas "no formales" de la construcción nacional episodios importantes que resaltan el papel de las regiones en la forma como se ha estructurado el conflicto, así como otras múltiples relaciones sociales con el territorio. articulate the process to the country's inland with real regional impact.

Another elements that the displaced population demographic territorial placement and demographic displacement analysis shows, it is part of the conflict's cause itself, among which outstands displacement caused by land accumulation which directly relates to the above mentioned related to economic motivations to reorganized the territory.

Although the land accumulation is by itself violent, the distinction made here, allows showing that in most regions, 7 out of 10 , displacement cause is due to land accumulation. It is obvious then how the counter reform process has very negative consequences for the population whose land is expropriated, in many cases land that inherited by generations, to be aliens in their own land.

The conflict's comprehensive scope is every day more evident in the governmental interventions, nevertheless the "no formal" important national construction dynamics episodes have out stood the regions important role as how they have structured the conflict as well as many other social relationships with the territory. 
En este contexto se precisa de políticas que asuman la importancia de la configuración regional y las formas de ocupación del territorio para la elaboración de propuestas y la definición de lo que puede ser un proceso que reconozca las nuevas realidades de la población, evitando al máximo generar traumatismos y choques tanto a la población desplazada que ha logrado ubicarse en el lugar de llegada como a la población residente o raizal adonde llegan los desplazados para convertirse en uno más dentro de los miles de pobres que transitan solitariamente la ciudad.

\section{BREVE REFLEXIÓN SOBRE LOS PROBLEMAS DEL HÁBITAT Y LA VIVIENDA EN AMÉRICA LATINA Y COLOMBIA}

Las etapas recientes del crecimiento de la urbanización en América Latina han estado mediadas por la búsqueda de la construcción de racionalidades en la planeación, pretendiendo mediante el impulso de planes reguladores, planes maestros, planes estratégicos, entre otras figuras, armonizar los procesos de estructuración y ordenación del territorio urbano. Sin embargo, éstos no han producido la respuesta esperada; muy por el contrario, el avance de la ciudad en todos sus órdenes refleja la construcción social de un territorio desestructurado y fragmentado como resultado de los modelos de desarrollo económico
Within this context it is key that regional configurations and territory occupation methods are taken in consideration when new policies are formulated and defining what process could recognize the population's new realities avoiding as much as possible clashes and traumatism between the displaced population and the existing residence in these new places they have settled to become one more of them among the thousand that live in the city.

\section{BRIEF REFLEXION ON HOUSING AND HABITAT PROBLEMS IN LATIN AMERICA AND COLOMBIA}

The latest urban growing stages in Latin America has been led by searching rational construction planning through urban planning regulations, master plans, strategic plans among other initiatives to harmonize urban territory structure and management. Nonetheless this has not produced the expected results, on the contrary social construction growing has developed in fragmented, and unstructured ways due to the economic models imposed not taking in consideration 
impuestos por fuera de los contextos presentes en América Latina y el Caribe.

Modelos de desarrollo generalmente desequilibrados, que no construyen equidad y pretenden obtenerla por vía de la simple regulación; encontrando que estas lógicas de actuación generan todo tipo de tensiones que se manifiestan en la ciudad, tensiones marcadas por la desigualdad. Tensiones que a nivel del territorio se expresan con búsquedas y respuestas individuales a la solución de los problemas como los del hábitat y la vivienda, los cuales terminan siendo resueltos por la mayor parte de la población por el mecanismo de la auto producción, como única vía alternativa frente a la imposibilidad de cumplir con las exigencias establecidas por el mercado formal.

El caso colombiano no es diferente al del resto de Latinoamérica, lo que sí presenta son rasgos particulares derivados del conflicto interno que se manifiestan en las ciudades, tanto en términos de planeación y control territorial por parte del establecimiento, como por la ampliación de las demandas de bienes y servicios de la ciudad debidas a los flujos permanentes de población desplazada que llega a estos territorios.

Bajo este panorama cabe hacerse la siguiente pregunta: ¿Han existido políticas de asentamientos humanos en Colombia?
Latin America and Caribbean current context reality.

These development models are usually unbalanced which do not build equity and try to get it through regulations just finding numberless tensions and problematic behaviors within the cities', inhabitants, tensions that show acute inequalities among its inhabitants. This tensions result in individual search for answers to their housing and habitat needs in the territory which usually ends by population self housing production as the only alternative due to the impossibility to meet existing formal market demands.

Colombia's case is not any different from the rest of Latin America, although it has its own particular characteristics derived from the internal conflict that shows in the cities both planning as well as territorial control terms to settle also in goods and services demands enlargement due to the new displaced population arriving to the cities.

Have human settlement policies existed in Colombia? How can we answer this question in this context? 
Así como frente a la mayoría de aspectos que integran la vida social, el tema de vivienda no ha contado con desarrollos profundos y coherentes con las necesidades, en torno a la problemática de los asentamientos humanos. Muchos de los procesos adelantados desde el sector público sobre la resolución de la problemática han llevado a acercamientos leves sin estructurar políticas integrales y de largo plazo.

En el caso de los asentamientos humanos, se han presentado soluciones fragmentadas de urbanización que antes de evaluar la conveniencia de las transformaciones para los habitantes y pobladores, se han centrado en las dimensiones físico espaciales de proyectos utilizados más como muestras exploratorias de las fórmulas de planeación copiadas de otros países que como alternativas reales a las demandas sociales.

En este sentido, se puede afirmar que en Colombia aún no existen políticas para los asentamientos humanos de carácter satisfactorio que cuente con capacidad de respuesta y cubrimiento de los déficit cuantitativo y cualitativo acumulados.

La negativa respuesta a la pregunta aquí planteada lleva a la necesidad de explicar cuál ha sido entonces el fenómeno de desarrollo urbano vivido en Colombia y, dentro de éste, el papel del hábitat y la vivienda.
As most of the aspects that are part of the social interaction, housing issues have not developed the coherent deep necessary approach to solve housing needs. Many of the public sector processes deal with this problem and had only mild advances lacking integral and long term structure policies.

"Only partial urbanization solutions have been proposed in human beings settlements cases before assessing the people's own interest related to these transformations. They have focused in the projects' physical-spatial dimensions using them more as planning explorative formulas samples copied from other countries as social demands real alternatives than addressing the real needs of the population."

So we can say that Colombia has not developed human settlement policies that satisfy the scope and answers needed to tackle the existing accumulated quantitative and qualitative deficit.

The negative answer to this question takes us to explain the real urban development phenomenon in Colombia and the housing and habitat role in it. 
Hay elementos que se comparten con claridad en las problemáticas del hábitat y la vivienda en la región. Entre ellos encontramos una tendencia generalizada a priorizar las políticas cuantitativas sobre las cualitativas, la aplicación de modelos que no se adecuan a las características ambientales, geográficas y de contexto, la falta de mecanismos de participación ciudadana adecuados y una ausencia de esquemas para la renovación y repoblamiento de los centros urbanos deteriorados en busca de ciudades más compactas y menos extensivas, como hasta ahora han sido. Esto en gran medida es consecuencia de una falta de vinculación entre la planificación urbana y la planificación sectorial del hábitat y la vivienda.

Señalar, entonces, los nuevos conflictos en la ciudad, significa partir por reconocer las principales contradicciones acumuladas, al igual que aquellas que aún no han logrado ser resueltas y que a pesar del paso de los años siguen requiriendo de atención prioritaria. Entre las contradicciones presentes están los relacionados en materia de una adecuada habitabilidad y el acceso a la vivienda, los cuales siguen generando conflicto y están presentes en todas las ciudades colombianas.

Se podría afirmar que el modelo de la ciudad colombiana está marcado por la superposición de trazas urbanas formales e informales articuladas mediante elementos constitutivos de la estructura vial y las redes de servicios públicos domiciliarios. Allí el llamado sector informal continúa siendo hoy
There are common elements with the region's housing and habitat problems, among them, the tendency to privilege quantity over quality problem solving policies; inadequate model implementation to the region's environment, geographic and context characteristics; lack of adequate citizen's participation mechanism; deteriorated urban centers renovation and repopulation schemes to create compacted and less extended cities as it has been up to now. This is mainly due to the lack of urban planning and housing and habitat sector planning.

Pointing out new conflicts in the city means to start to recognize the accumulated contradictions as well as the ones that are priorities and have not been able to be solved through the years. One of them is the accessibility to housing and inhabitability which still are problems in Colombian cities.

It can be said the Colombian city model are marked by formal and informal urban design superposition articulated through consecutive street structure as well as utilities public services networks. The informal sector in that area still is up to now the great builder in Colombia and Latin America which is 
el gran constructor de Colombia y América Latina, el cual presenta un dinamismo continuo frente a los bajos niveles de respuesta y acción del sector oficial.

Se debe construir entonces, una relectura de la ciudad, el hábitat y la vivienda de manera colectiva, que recoja la diversidad y complejidad existente en los territorios urbanos, donde se reconozca la existencia de lo informal, y se encuentre con las vías tradicionales de actuación desde lo formal para coincidir en las soluciones que se requieren, en un proceso de superación de cada una de estas formas de hacer y ser ciudad.

El reto de la ciudad futura radica en la construcción colectiva de las políticas públicas para la ciudad y en ella el hábitat y la vivienda, junto a instrumentos de gestión y regulación urbana compartidos, que superen el papel y se materialicen en la realidad, tanto en su configuración como en su aplicación, a partir del desarrollo de un enfoque que se sitúe en el contexto actual del conjunto de sus ciudadanos y los considere como iguales. Se trata de garantizar lo público como un bien común colectivo y no de intereses particulares.

\section{ALGUNOS RASGOS DE LA SITUACIÓN DE VIVIENDA DE LA POBLACIÓN DESPLAZADA EN COLOMBIA}

La vivienda en el caso de la población desplazada conlleva varias connotaciones, a las cuales se refiere el documento a continuación; entre ellas dynamic compared to the official sector low response level index.

A city collective housing and habitat view must be done, one that takes in consideration urban territory diversity and complexity as well as its informal growing that meets the formal ones in order to find the required solutions to the problem.

The future city challenge lies in housing and habitat collective construction public policies linked to management and urban regulation instruments that go beyond paper and become part of the city's reality. It has to develop an approach that sees them as equal and includes the current set of cities context in its configuration as well as its implementation. The objective is to guarantee a common collective well being and not merely particular single interest.

\section{SOME HOUSING CHARACTERISTICS OF DISPLACED POPULATION IN COLOMBIA}

Displaced population housing has various features, among them urban informality as a real alternative and the real problem behind is the lack of regular income, some 
están la informalidad urbana como alternativa real y el problema de fondo -la falta de ingresos estables-, algunas particularidades de la población desplazada, los problemas generales relacionados con el acceso a la Vivienda de Interés Social -VIS ${ }^{19}$ - y la Vivienda de Interés Prioritario -VIP ${ }^{20}$-, el mercado inmobiliario y la política actual de vivienda.

Como problemas generales cabe reiterar que históricamente no ha existido una política de asentamientos rurales, como tampoco ha existido un modelo habitacional claro para lo rural o lo urbano. La magnitud de la problemática y la complejidad de la misma no ha sido abocada de manera decidida por las políticas públicas que se han promovido, no han contribuido de manera decisiva a la resolución de las problemáticas generadas, encontrándose en el caso de la vivienda un agravamiento del problema de la VIS y VIP para sectores de bajos ingresos y dentro de ellos la población desplazada. Ello reforzado desde la década de los 90, mediante la transferencia de la responsabilidad del Estado a los particulares (mercado) en esta materia.

El problema de la VIS y la VIP en general es complejo, ya que no logra atender los requerimientos de la

19 La Vivienda de Interés Social -VIS- , es aquella que tiene como precio techo los 135 Salarios Mínimos Mensuales Legales Vigentes -Smmlv- (67.095.000 pesos de 2009, 32.300 Usd aproximadamente). La Vivienda de Interés Prioritario -VIP- , es aquella que tiene como precio techo los 70 Smmlv (34.790.000 pesos de 2009, 16.750 Usd aproximadamente). peculiarities of the displaced population, the usual problems related to Social Interest Housing access- VIS ${ }^{19}$ and the Priority Interest Housing- VIP ${ }^{20}$, real estate market and current housing policy.

Both historical inexistent settlement policy and a clear rural or urban housing model are usual problems. The issue's magnitude and complexity has not been properly addressed by public policies, they have not contributed to solved the generated problems and in VIS and VIP particular case, it has aggravated for low income people for different reasons among them, displaced population. This has been reinforced since the 90's through State responsibility transferred to private sector (market) in this area.

The VIS and VIP problems are complex as they do not fill the population required needs demand, so even less displaced population. A precarious offer is available regardless

19 La Vivienda de Interés Social-VIS (social interest housing), it is the one that has the price limit of 135 current existing monthly minimum salary (Salarios Mínimos Mensuales Legales Vigentes -Smmlv) (67.095.000 pesos in 2009, 32.300 US dollars approximately).

20 La Vivienda de Interés Prioritario -VIP- (Priority Interest Housing), it is the one that has as price limit 70 (Smmlv 34.790 .000 pesos de 2009, 16.750 US dollars approximately)

ARTICLE: Housing for displaced population in Colombia. Public policy and law enforcement Recommendations / Carlos Alberto Torres Tovar, Johanna Eloísa Vargas Moreno. 


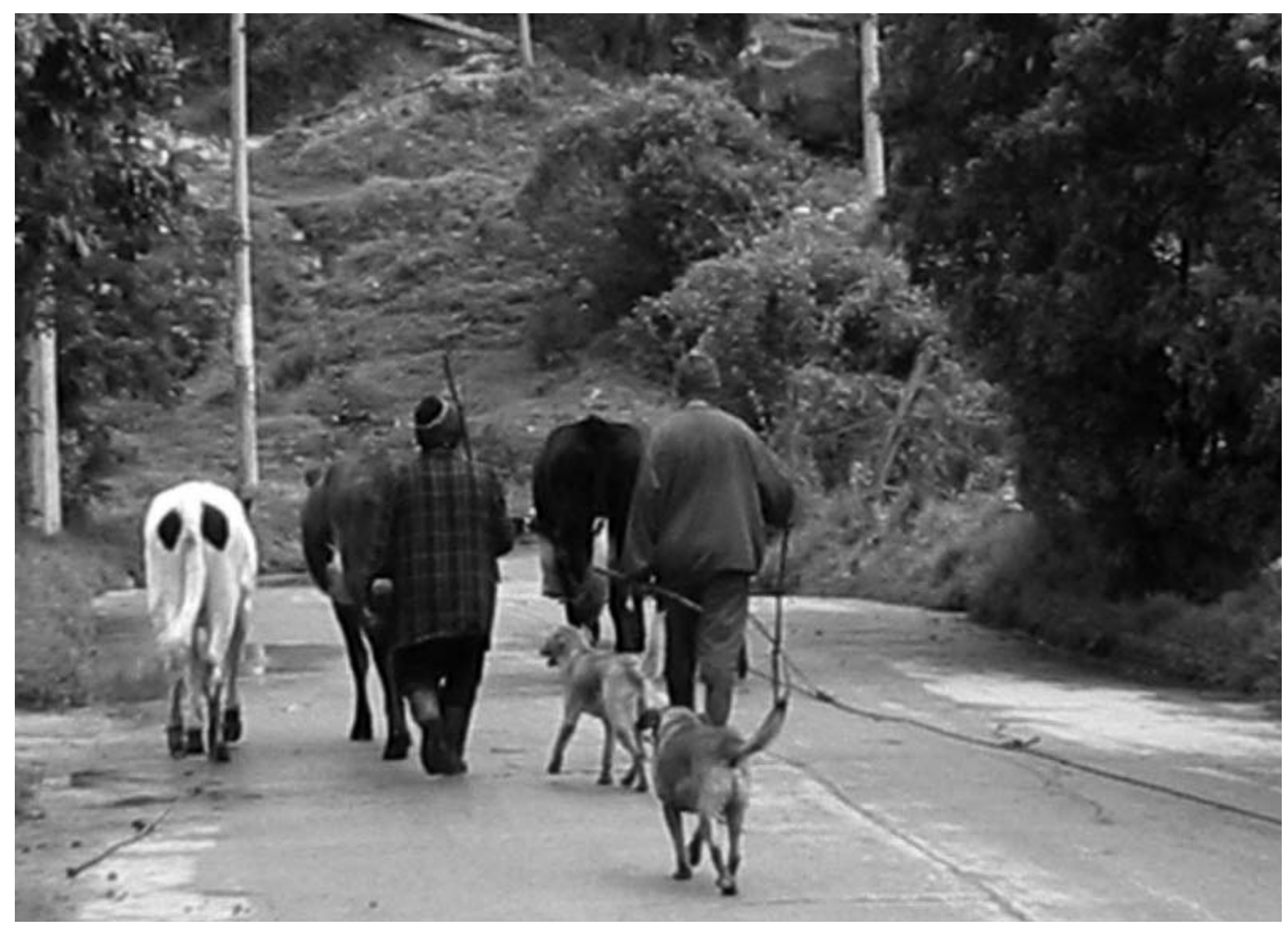

Entre lo rural y lo urbano. Foto de habitantes amenazados por desplazamiento interno del barrio San Luis ubicado en la periferia nororiental de Bogotá D.C.

Fuente de la Fotografía: Johanna Vargas, 2008.

Between rural and urban. Inhabitants threaten by internal displacement in San Luis neighborhood in northeast periphery in Bogota D.C. picture Photography source: Johanna Vargas, 2008.

ARTíCULO: Vivienda para población desplazada en Colombia. Recomendaciones para la política pública y exigibilidad del derecho / Carlos Alberto Torres Tovar, Johanna Eloísa Vargas Moreno. 
población demandante y menos aun de la población desplazada. Se presenta una precariedad de la oferta a pesar de la existencia de Subsidios Estatales Múltiples $^{21}-2$ o más subsidios que concurren para financiar la VIP-, y no se garantiza el acceso a una solución adecuada, satisfactoria y digna. Entre los factores determinantes de esta situación está la fuerte especulación que se presenta por el valor del suelo urbanizable.

Asímismo, el acceso a una unidad habitacional, ya sea VIS o VIP, no representa una solución definitiva al problema de la vivienda dado que la VIP (32 mts2) producida no garantiza unas condiciones básicas de habitabilidad. Esta situación lleva a que hoy día se presente una informalización de la vivienda formal, que pasa de ser una "solución" a convertirse nuevamente en un problema, ante la ausencia de acompañamiento para su desarrollo progresivo.

Ello refleja que el monto del subsidio estatal otorgado no alcanza para una vivienda digna, cuyo consumo se dificulta aún más cuando la propiedad y la titulación generan una serie de costos que aparecen hoy en día más como tasas impositivas. Sin embargo, es preciso aclarar que aunque estos

21 Para aplicar a los subsidios estatales de vivienda se suman dos factores: ingresos familiares y puntaje asignado por la Encuesta SISBEN (Sistema de identificación de potenciales beneficiarios de programas sociales), sumado al valor final del bien que se desea adquirir. Los subsidios oscilan entre 1.988 .000 (4 Smmlv, 950 Usd aproximadamente) y 10.934 (22 Smmlv, 5250 Usd aproximadamente). the Multiple State Subsidies ${ }^{21}$ - two or more subsidies are present to finance VIP and there is not guarantee of an appropriate, satisfactory, deserving solution. Among the defining factors in this situation is the land's feasibility to be urbanized speculation value.

The access to a housing unit, either VIS or VIP does not represent a final solution to the housing problem due to the fact that VIP (32mts2) produced does not guarantee habitability basic conditions. This situation leads to the current formal housing informality that in order to be "solution" becomes once again a problem due to the lack of progressive development follow-up.

This means that the State's subsidy is not enough for a proper housing unit which makes it even more difficult to meet with the legal requirements to hold the property's deed expenses that nowadays are more a tax rate. Although it is important to clarify that this costs are related to any kind of possible

21 Two factors are added to apply State's housing: assigned score to family income by the SISBEN Survey (Identification system of social program potential beneficiary or Sistema de identificación de potenciales beneficiarios de programas sociales), added to the wanted property final value. The subsidies are between 1,988,000 (4 Smmlv, 950 US dollars approximately) and 10,934 (22 Smmlv, 5,250 US dollars approximately). 
costos están asociados a cualquier tipo de solución que se ofrezca a la población desplazada, es preciso tener en cuenta que no por eso deben quedar bajo la responsabilidad individual. Ante la magnitud de la crítica situación del desplazado, estos costos deben hacer parte de la solución ofrecida por el Estado.

Las dificultades generadas por los excesivos trámites, los procedimientos existentes y la imposibilidad de ser sujetos de crédito por no demostrar capacidad de ingresos y de pago suficientes, limitan aún más el acceso a la vivienda producida formalmente. Es por ello que la Informalidad Urbana se ha constituido en la alternativa real para la población desplazada.

Así, el desplazamiento fortalece la configuración informal de la ciudad, contribuyendo a agudizar una condición de por sí problemática y poco digna de habitabilidad. A los pobres históricos existentes deben sumarse los desplazados, quienes encuentran solamente esta vía para resolver su "derecho a la vivienda" y, en sentido estricto, garantizarse un techo para vivir.

Se reconoce así que la necesidad de un techo prima sobre el tema del riesgo que representa su localización en áreas primordialmente de la periferia y borde urbano, en suelos no aptos para urbanizar, con presencia de múltiples vulnerabilidades. Sin embargo, por encima de estas condiciones, la localización en la ciudad le permite a la población desplazada mejorar su calidad de solution offered to the displaced population, this does not mean that it should be left to individual responsibility due to the displaced population critical condition. These expenses must be included in the State's possible solution.

The difficulties generated by the excessive legal papers, the current procedures and the impossibility to be subjected to credit as they can not meet the financial institutions requirements to grant a credit such as income or credit's payment capacity, limits even more formal housing access, reason why informal solutions have become the real displaced population alternative.

Displacement favors the cities' informal configuration, contributing to worsen habitability problematic condition. To the historic poor people must be added the displaced ones which are only on the road to solve their "right to housing" and strictly speaking guarantee a roof to live.

It has to be acknowledged that the need for a roof goes beyond the risk to be placed in the cities' periphery, urban border, and unsuitable land to urbanize with multiple vulnerabilities. Nevertheless above these location conditions 
vida en términos de acceso a la oferta de servicios públicos domiciliarios y equipamientos colectivos ya instalados, así como le posibilita construir oportunidades para la obtención de recursos económicos -así sea por la opción del denominado "rebusque"-.

Este tipo de solución también le permite al desplazado la reproducción de las condiciones de subsistencia, ya que la vivienda informal no es exclusiva para descansar y alojarse, sino que es ante todo una unidad productiva que permite la generación de ingresos.

Se debe señalar que esta alternativa de solución no es pues nada novedosa si recordamos que los asentamientos humanos de origen informal datan, en el caso colombiano, desde fines del siglo XIX, pero cobran mayor relevancia tanto en cantidad como en variedad después de mediados del siglo pasado cuando se dinamizo el proceso de urbanización de las ciudades colombianas. Para comienzos de este siglo, la proporción que representan los territorios urbanos configurados informalmente es de aproximadamente el 25\% del área construida en sus ciudades, lo cual asciende a más de 30.145 hectáreas en todo el territorio nacional. ${ }^{22}$

Por su parte, el mercado a través de la denominada industria de la construcción y del mercado

22 DNP. 2004. displaced population can improve their quality life in terms of utilities public services and collective amenities installed as well as allow constructing opportunities to access to economic resources, even if it is by the means as what is called "rebusque" (research).

This type of solution allows the displace population to reproduce the subsistence conditions, as informal housing it is not a lodging and resting place, though above all a productive unit that allows generating income.

It must be pointed out that this alternative it is not new at all as informal human settlements are dated, in the Colombian case, since the latest XIX century, though have a greater quantity relevance as in variety after the middle of last century that Colombian cities' urbanization process was energized. Early this century approximately 25\% of the built cities' area is informal configured urban territory which is 30,145 hectare in the whole national territory. ${ }^{22}$

On the other hand the real estate market and the so called construction industry insist there

22 DNP. 2004. 
inmobiliario insisten en que no hay condiciones para atender estas demandas, al no existir suelo urbano disponible, que sumado a las dificultades de las condiciones financieras no permiten obtener las rentabilidades esperadas.

Desde esta lectura la oferta para VIS y VP siempre es insuficiente; no hay oferta de suelo urbano para atender esta demanda, ya que el suelo disponible se privilegia para atender otras actividades más rentables. Al sector privado y particularmente la denominada industria de la construcción no le interesa la VIS y menos aun la VIP, ya que no generan la rentabilidad deseada, principalmente esta última. Las curvas del mercado inmobiliario evidencian que ésta es una opción para el sector privado, solamente en los momentos en que la concentración de capitales para producción de vivienda para altos estratos decae. La VIS y la VIP se han convertido en el "colchón" del sector privado, antes que una alternativa estratégica de su producción.

Es entonces evidente que la política actual no es adecuada, y en el caso de la población desplazada no permite alcanzar unos Básicos Vitales relacionados a la vivienda. La política de vivienda para la población desplazada se traduce en la asignación de subsidios para la compra en el mercado de una VIP, dándosele el mismo tratamiento que el de los pobres históricos de la ciudad y colocándolos a competir por la misma bolsa de recursos. are no proper conditions to meet these demands, as no urban land is available, adding to the financial conditions difficulties which do not allow them obtaining the expected profitability.

From this point of view VIS and VP are always insufficient; there is not urban land to meet this demand as the available land is privilege for other type of more profitable activities. Private sector and particularly the construction industry are not interested in VIS and even less VIP as they do not offer the desirable profitability, especially the last one. The real estate market curves show that this is only an option in those times capital concentration for high income housing production decreases. VIS and VIP has become the private sector "mattress" more than a strategic production alternative.

It is evident then that the current policy is not adequate and in the displaced population does not meet the Vital Basic related to housing. The displaced population housing policy translates in subsidies assignation to buy a VIP in the market, giving them the same treatment that the cities' historical poor population, making them compete for the same bag of resources. 
Con la política de vivienda reducida a acciones de subsidios monetarios (con frecuencia otorgados de mala manera), el Estado le traslada la responsabilidad al sector privado, quien orienta dicha asignación al cumplimiento de sus intereses, muchas veces contrarios a los de las poblaciones vulneradas. Los recursos no son oportunos ni en cantidad (valor), ni en oportunidad (tiempo), y el acceso a los subsidios por sí solos tampoco solucionan el problema. Aun si todos tuvieran subsidios, el problema que se mantiene de fondo es que no existe una oferta de vivienda para los sectores de población de más bajos ingresos.

Asimismo, en relación a la vivienda ofertada, su calidad depende de la financiación, lo que implica que dada la precariedad de recursos que posee esta población, se trata de una vivienda inadecuada (problemas en la estructura de los pisos, problemas de hacinamiento, dificultades para el acceso a servicios públicos domiciliarios y limitación de espacios adecuados para realizar las funciones básicas al interior de la vivienda).

Se debe resaltar que el problema de fondo se constituye en una suma de falencias donde lo fundamental no resulta ser la vivienda y la obtención de un hábitat digno, sino la generación estable de ingresos para la reconstrucción de procesos y relaciones vitales en todos los ámbitos que configuran la vida de cualquier persona. Bajo esta consideración cabe observar que los desplazados
Reducing housing policies to money subsidies (usually badly given), the State transfer the responsibility to the private sector that meets this assignment in terms of their own interest, many times contrary to the vulnerable population. The resources are not enough neither in quantity (value) nor opportunity (time) and the subsidies access does not solve the problem by itself. Even if everybody got a subsidy the problem is not solved as there is not enough housing offer for this type of low income housing.

On the other hand the quality of this housing offers depends on funding and due to this segment of the population precarious resources is an inadequate housing (floor structure problems, utilities difficult access and limited interior space for basic house functioning).

It real problem is a number of failures which is not the appropriate housing itself nor decent habitat access, but stable income generation for the reconstruction of the normal life processes and vital relationships everybody has. Under this perspective, displaced population do not have access to banking nor credit and if they have access to housing; 
no son objeto de bancarización, como tampoco sujetos de crédito. A ello se suma que en el caso de que obtuvieran asequibilidad a la vivienda, deberán generar ingresos suficientes para poder pagar la deuda, los servicios públicos, las tasas impositivas y todos los costos que se derivan de la vivienda formal, como se ha mencionado.

Por otra parte, la política de asignación de subsidios estatales a la vivienda no reconoce las particularidades de la población desplazada, entre las cuales se pueden enumerar:

- Múltiples tipologías de agrupación de la población en condición de desplazamiento: familias nucleares y extendidas, mujeres cabeza de hogar, individuos, etc.

- La mayoría de la población desplazada que llega a las grandes ciudades se ubica en asentamientos informales, muchos de ellos en lugares de alto riesgo (inundación, remoción en masa, contaminación, emisiones de gases y radiación).

- Asímismo se ha de reconocer que la ciudad permite mimetizar al desplazado frente a la dimensión del conflicto, por una parte, y de otra los aparta de su condición de productores y propietarios a la de consumidores y desposeídos. then they have to produce enough income to be able to pay the debt, public services and tax rates and every single expense a formal housing implies as it has been mentioned.

On the other hand State housing subsidies assignation policy does not recognize the displaced population particularities such as:

- Multiple population grouping typologies in displaced conditions: extended and nuclear families, women head of household, single people, etc,

- Most of the displaced population that arrives to big cities locates in informal settlements, many of them in high risk places because of floods, contamination, gases and radiation emission, mass removal.

- The city allows mingling displaced population and move away from the conflict's consequences; though on the other hand they become bit outcasts as they have lost their properties and previous life, starting back again in very precarious situation. 
Por otra parte, la oferta de VIP no considera las características de la vivienda rural. Vivienda que si se asemejara a la Unidad Agrícola Familiar - $\mathrm{UAF}^{23}$ no es equiparable bajo ninguna circunstancia a la vivienda "mínima" urbana. De igual modo, el tamaño del hogar desplazado (5.1 habitantes por hogar ${ }^{24}$ ) es mayor al promedio del tamaño del hogar urbano colombiano (3.9 habitantes por hogar). La disponibilidad de espacios en la VIP no contempla este aspecto, propiciando condiciones de hacinamiento e insalubridad. Tampoco contempla las características regionales y culturales que deberían permitir una vivienda diferenciada. En general, la VIP o VIS ofrecida por el mercado estandariza su producción a una "familia tipo" en función de la cantidad de dinero que hay por cada metro cuadrado ofertado.

Por último, es necesario reafirmar que no es posible equiparar los bienes abandonados con una solución habitacional tipo VIP en la ciudad, ya que los grupos familiares que dejaron abandonadas tierras, fincas y/o casas en el desplazamiento

23 "Se entiende por Unidad Agrícola Familiar (UAF), la empresa básica de producción agrícola, pecuaria, acuícola o forestal cuya extensión, conforme a las condiciones agro ecológicas de la zona y con tecnología adecuada, permite a la familia remunerar su trabajo y disponer de un excedente capitalizable que coadyuve a la formación de su patrimonio". Ley 160 de 1994. Artículo 38.

24 Corresponde con los hogares incluidos en el Registro Único de Población Desplazada -RUPD- que coordina la Agencia Presidencial para la Acción Social y la Cooperación.
On the other hand VIP offer does not consider rural housing characteristics. If it was similar to Family Farm Unit housing - UAF ${ }^{23}$ - it is by no means similar to the "minimal" urban housing. The size of the displaced population housing (5.1 inhabitants per home ${ }^{24}$ ), it is larger than the average Colombian urban house size (3.9 inhabitants per home); space availability in the VIP does not take in consideration this aspect and fosters overcrowded and unsanitary ones. It does not take in consideration either regional or cultural characteristics that would allow different housing. VIP and VIS market offers standardizes production to a "type family" in relationship to the amount of money available for each squared meter offered.

Lastly it is necessary to remember that is not possible to match the abandoned property with a VIP housing solution in the city, as family

23 "Unidad Agrícola Familiar (UAF) Family Farm Unit is the basic agricultural production company, livestock, aquaculture, and forestry, its extension has to meet the zone's agro-ecological conditions and with the adequate technology that would allow the family generate the necessary income, exceeding its capital to help form its patrimony". Law 160, 1994. Article 38.

24 It matches the homes included in the (Registro Unico de Población Desplazada -RUPD-) National Displaced Population Single Register that coordinates the Presidential Agency for Social Action and Cooperation. 


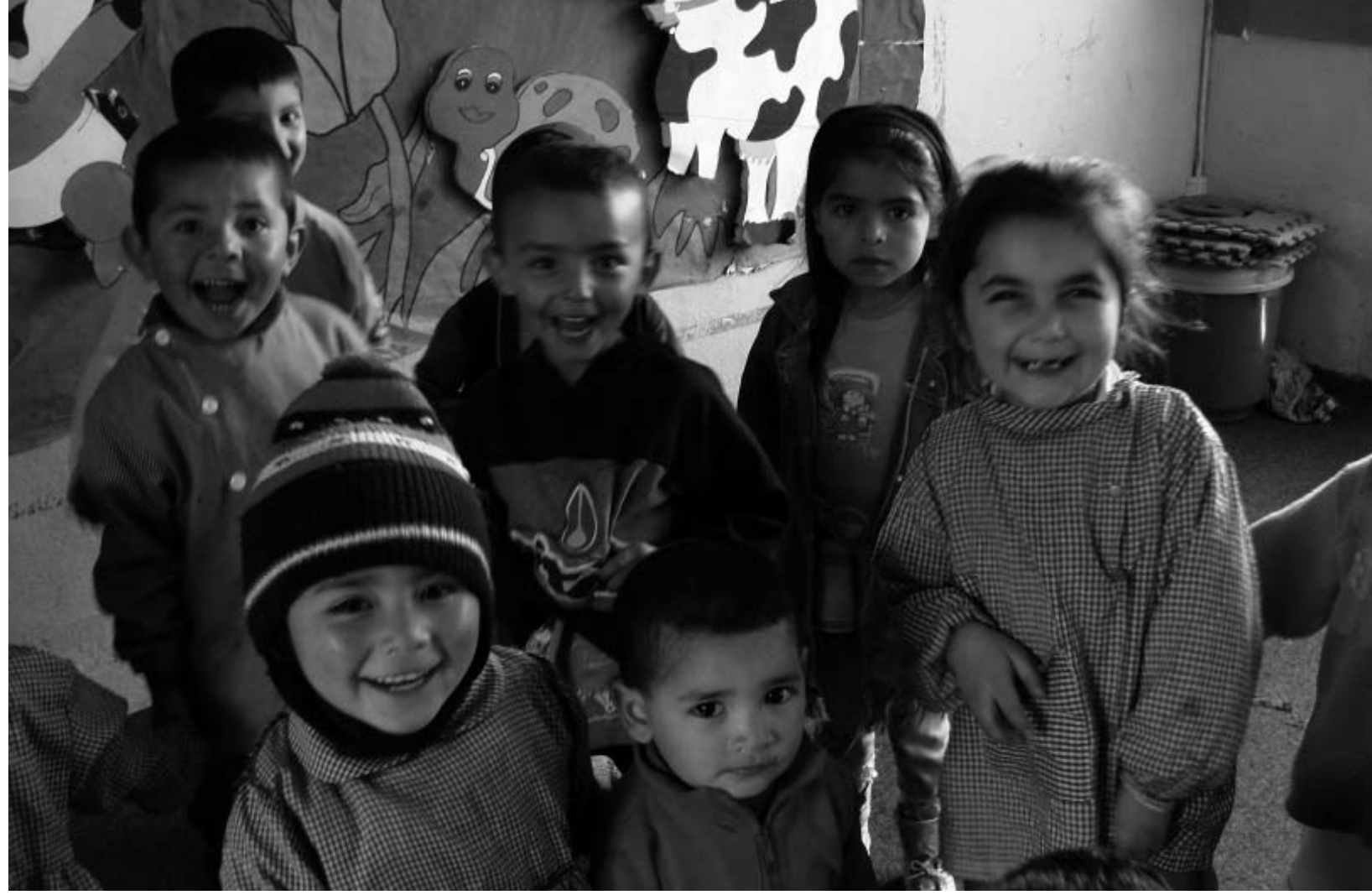

Solo risas. Niños y niñas hijos del desplazamiento en todas sus escalas (nacional, regional y local) en casa atendida por madre comunitaria del barrio La Esperanza en Usme - Bogotá D.C.

Fuente de la Fotografía: Johanna Vargas, 2008.

Only laughter. Displaced children in all the scale (national, regional and local) taken care by a La Esperanza neighborhood communitarian mother in Usme. Bogota D. C.

Photography source: Johanna Vargas, 2008.

corresponde al $73,4 \%$ del total de la población desplazada ${ }^{25}$. Ello denota que el slogan propuesto en el Plan Nacional de Desarrollo 2002-2006, "Colombia un país de propietarios"26, compite con la realidad al ser "Colombia un pais de

25 Comisión de seguimiento a la política pública sobre el desplazamiento forzado. 2008.

26 DNP. 2002. groups that left land, farms and/or houses is $73,4 \%$ of the total displaced population ${ }^{25}$. This shows that the slogan proponed by the National Development Plan 2002-2006 "Colombia, a country of property owners" ${ }^{26}$ competes

25 Comisión de seguimiento a la política pública sobre el desplazamiento forzado. 2008. Forced displaced public policies follow up committee, 2008.

26 DNP. 2002 
expropiados”. La población desplazada tenía una relación de propiedad, de posesión o de ocupación con el bien, en el 88,9\% de los casos. Por ello no se puede equiparar el valor de la propiedad en suelo rural y su extensión -UAF-, frente al valor de la propiedad urbana y su extensión -VIP-, como ya se había señalado.

Las familias (u hogares) desplazados beneficiados con subsidios estatales para vivienda correspondieron a 12.973 (en el año 2002) hasta alcanzar 52.154 (en el año 2007), con un monto asignado a la fecha de 2.8 billones de pesos ${ }^{27}$.

\section{Construcción de alternativas para garantizar el derecho a la vivienda de la población desplazada}

Sobre la base de la caracterización de las problemáticas del conflicto interno, el desplazamiento forzado y las dificultades para el acceso a una vivienda digna, expuesta en el aparte anterior, se presentan a continuación una serie de elementos a manera de recomendaciones de política pública, los cuales se consideran pueden ser tenidos en cuenta para la elaboración de propuestas encaminadas a superar la débil

27 Equivalen a 1.400 millones de dólares.

54 revista invi № 66 / Agosto 2009 / Volumen № 24: 17-86 with reality as "Colombia is a country of expropriates". The displaced population had a property relationship, property possession or occupation in $88,9 \%$ of the cases and for that reason is not match able to the property value on rural land and its extension-UAF in relationship to the urban property value and extension -VIPas it was previously mentioned.

The displaced families (or households) benefit by State's housing subsidies correspond to 12,973 in 2002 to reach 52,154 in 2007 with a 2.8 billion pesos assigned. ${ }^{27}$

\section{Construction of alternatives to guarantee the right of housing of the displaced population}

Based on the internal conflict problem's characterization, forced displacement and their difficulties to access to a decent home, as was mentioned before, a series of recommendations are made to take in consideration for possible public policy making to improve the previous weak State intervention to solve forced displacement

271.400 million dollars. 
actuación del Estado para resolver la situación del desplazamiento forzado y en particular el acceso y disfrute del derecho a la vivienda.

Ello en el entendido que el acceso a una vivienda digna no resuelve y elimina la necesidad de garantizar la verdad, la justicia, la reparación y el derecho a la no repetición.

\section{ENFOQUE PARA LA CONSTRUCCIÓN DE ALTERNATIVAS}

Plantear propuestas encaminadas a la solución de las problemáticas de la población desplazada, es un ejercicio necesario y urgente. Sin embargo, es preciso antes de producir una serie de iniciativas de acción buscar los elementos de encuentro y correspondencia entre la caracterización de la problemática y dichas acciones.

Se parte, entonces, por entender el desplazamiento forzado como uno de los elementos estructurales del actual conflicto interno, de carácter armado, marcado por las problemáticas sociales y políticas colombianas (tal y como ha sido desarrollado en el aparte anterior). En este sentido, las alternativas propuestas no pueden desconocer este contexto o seguir orientadas hacia el asistencialismo como respuesta, hasta hoy preponderante.

Es preciso que el enfoque desde el cual se proponga cualquier iniciativa esté centrado en la necesidad situation and particularly the right of housing access and enjoyment.

Understanding that having access to a decent housing, does not solve nor eliminates the need to guarantee truth, justice, reparation and the right not to repeat the situation again.

\section{APPROACH FOR CONSTRUCTION OF ALTERNATIVES}

To propose possible alternatives to tackle the displaced population problem it is a necessary andurgentneed, nevertheless it isvery important to first produce a series of actions initiatives to find meeting points and correspondence between the problems characteristics and these actions in particular.

It is important to understand forced displacement as a structural element of the current internal conflict, armed conflict, framed by Colombia social and political problems as it has been previously mentioned. The alternatives proposed within this context cannot be overlooked or provide welfarism as an answer, up to now the approach given.

It is essential that any approach taken centers its initiatives in the need to articulate the multiple 
de articular las múltiples necesidades y apuestas del conjunto social así como sus soluciones, entre las cuales se pueden mencionar la solución al conflicto interno, el restablecimiento de derechos, la dignificación de la población desplazada, de la población vulnerable y pobre, las garantías para el acceso y disfrute de toda la población a educación, salud, bienestar social, servicios con calidad y recreación, entre otros; así como de garantías para la libre expresión y organización.

"(...) es importante insistir en la necesidad de articular profundamente los procesos de reparación a procesos de reforma social que hagan sostenible la estrategia de paz." 28

El enfoque orientador de las políticas y acciones encaminadas a resolver cada uno de estos aspectos debe alejarse cada vez más de la sumatoria de proyectos y propuestas, hacia la elaboración y armonización de políticas públicas que bajo el liderazgo del Estado permitan superar cuantitativa y cualitativamente el actual estado de cosas. Proceso que solamente será posible en tanto se cuente con la suficiente voluntad política de los agentes políticos y sociales dinamizadores del conflicto, pero principalmente de los gobernantes, quienes deben encabezar todas las dinámicas de transformación económica, política, ambiental y socio - cultural requeridas.

28 ROMERO, Marco. 2006. Pág. 32. social groups needs and bets as well as its solutions, among which it can be mentioned the internal conflict solution; the rights restitution; the displaced population, vulnerable and poor population dignity given back; the access and enjoyment to education, health, social welfare, quality services, recreation among other to all the population as well as free expression and organization guaranteed.

"(...) it is important to stress the need to deeply articulate the reparation to social reform processes that make sustainable the peace strategy." 28

The guideline approach to policies and actions leading to solve each of these aspects has to distance from the projects and proposals' summative to the harmonization and elaboration of public policies lead by the State that would allow overcoming quantitatively and qualitatively the current states of affairs. A process that can only be possible if there is enough political will of the conflict drivers, political and social agents, though mainly from the people who governs that should lead all the economic, political, environmental and sociocultural transformations required.

28 ROMERO, Marco. 2006. P. 32. 
Alcances y Limitaciones de LA FOCALIzACIÓN de LA PoĹtitica PARA LA POBLACIÓN DESPLAZADA.

En este orden de ideas uno de los principales aspectos a tener en cuenta está relacionado con la crítica evaluación que al día de hoy presenta la aplicación de políticas altamente focalizadas y de carácter asistencial, a través de las cuales el Estado ha buscado atender la problemática del desplazamiento.

Situación que se agudiza cuando dicho proceso de focalización termina restando recursos a los fondos de la política social y/o a otros programas de atención a población vulnerable y en condición de pobreza, como ha sido el caso de los recursos destinados para atender la demanda de vivienda de la población desplazada.

Marco A. Romero señala que bajo la consigna de no disponer de recursos el Estado ha venido justificando la falta de efectividad de la política, sin realizar mayores esfuerzos por garantizar otras fuentes de financiación,

"(...) el Estado no dispone de recursos, pero no demuestra empíricamente que haya desarrollado esfuerzos para obtenerlos a partir de estrategias de tipo redistributivos. (...) la realidad muestra que los programas destinados a la población desplazada no se están financiando con políticas redistributivas sino apelando al recorte de otros sectores sociales.
DisPlaced POPULATION POLICIES FOCUS SCOPE AND LIMITATIONS.

At this level of ideas one of the main aspects to take in consideration is related to the critical assessment that nowadays involves the application of such highly focalized policies of welfare character through which the States have tried to solve the displaced population problem.

A problem that worsens when the focus process subtracts resources from the social policies funds and/or other programs for people in vulnerable conditions or poverty as it has been the case with the assigned resources to solved the displace population housing demand.

Marco Romero says that the State by saying no resources available, has been justifying the lack of effective policies, not making any other effort to guaranteed other financing sources,

“(...) the State does not have resources, though it does not empirically show that has made any effort to obtain them through redistribution strategies. (...) reality shows that the displaced population targeted programs are not financed by redistribution policies, though through cutting budgets to 
En particular con los subsidios de vivienda, de salud y los recursos de crédito." ${ }^{29}$

Se propone entonces, enmarcar las soluciones y alternativas de política para la población desplazada dentro de una dinámica fuerte de reactivación de la política social agenciada por el Estado, donde sea posible evidenciar la distinción en la gestión, consecución y destinación de recursos para la Población Desplazada -PD- del resto de componentes de dicha política, pero que tanto una como la otra hagan parte de una verdadera política social, la cual,

"(...) debe partir de un principio de solidaridad basado en la redistribución del ingreso, en la financiación progresiva del gasto público y en la adopción de un modelo de desarrollo que permita la reactivación plena de la economía." 30

Superar la focalización y el asistencialismo en la política pasa por la creación de un conjunto de mecanismos que logren incluir distintos momentos de la problemática en los cuales se incluya la participación de la PD, desde el diseño, la planeación, gestión y ejecución, hasta la evaluación y seguimiento de las propuestas.

\section{LiderAZgo estatal.}

Como se ha venido señalando, es fundamental el liderazgo estatal en todas las escalas, para la

\footnotetext{
Ibíd. Pág. 29.

30 Ibíd. Pág. 29
}

other social sectors, particularly housing, health subsidies ad credit resources." 29

It is then proposed to frame policies alternatives and solutions for displaced population within a strong social policies reactivation dynamic agented by the State where it can be distinguished displaced population resources management, follow-up, and destination-DP-, from the rest of the elements part of that policy, though that all make a real social policy such as,

"(...) it must start in a solidarity principle based on income redistribution in the progressive public spending financing and in the development model adoption that allows full economy reactivation." 30

Overcome welfarism and focalization in politics goes through a set of mechanism creation that includes the different moments involved in the problem which incorporates DP participation from the design, planning, and management execution to the proposals assessment and follow-up.

\section{State's LeAdership.}

As it has been previously mentioned is essential a State leadership at all levels

$\begin{array}{ll}29 & \text { Ibíd. P. } 29 . \\ 30 & \text { Ibíd. P. } 29 .\end{array}$

ARTICLE: Housing for displaced population in Colombia. Public policy and law enforcement Recommendations / Carlos Alberto Torres Tovar, Johanna Eloísa Vargas Moreno. 
restitución de los derechos de la PD. Aunque es evidente que en la actualidad la construcción de políticas públicas depende del grado de concertación y articulación de múltiples agentes, también es claro que el gobierno nacional debe asumir integralmente la construcción de caminos viables y reales para que los derechos de la PD sean restablecidos absolutamente.

Para el caso de la vivienda debe éste brindar una oferta de vivienda que vaya más allá del subsidio y contemple todos los momentos del circuito de producción y consumo de ésta. Aunque la participación del sector privado es importante, debe ser el sector público quien lidere este esfuerzo, no solamente señalando los lineamientos para la producción de un hábitat y viviendas dignas, sino que en la medida de su responsabilidad debe adelantar una serie de actuaciones, algunas de carácter piloto, en las cuales se haga evidente la acción del Estado por ofrecer mejores y adecuadas soluciones a las que actualmente oferta el mercado.

\section{LA REgIÓN COMO EJE QUE CONCENTRA LA PROBLEMÁtICA PERO TAMBIÉN LA SOLUCIÓN.}

Como fue expuesto en la caracterización, se asume a la región como escenario territorial principal en donde se concentran los principales flujos de movilidad de la población desplazada. En este sentido, se propone que las alternativas de política sean diseñadas y ejecutadas desde el nivel central to give back the DP rights. Although it is obvious that currently the public policies construction depends on the multiple agents' agreement and articulation. It is also clear that the national government must undertake the integral construction of feasible and real alternatives to reestablish DP rights.

The housing case it should have housing offer beyond the subsidies that involves all the steps of the production and consumption process. Although the private sector participation is important it must be the public sector who leads the effort, not only giving the guidelines for habitat and housing production, though it also should anticipate a series of actions, some as pilot ones which show the State's actions improve, giving the appropriated solutions better to the current market offer.

THE REgION AS AXIS WHERE THE PROBLEM AND THE SOLUTION CONVERGE.

As it was shown in the characterization, the region is presumed as the main territorial scenery where the primary displaced population mobility flows merge. It is proposed that the policies alternatives are designed and executed at central level heading to the 10 emerging regions mentioned: Uraba, Middle 
con orientación hacia las 10 regiones emergentes mencionadas: Urabá, Magdalena Medio, Andina central, Montes de María, Piedemonte llanero, Frontera con Venezuela, Zona Bananera, Pacífico Central y la zona de frontera con el Ecuador, y en particular a las 9 ciudades que concentran la mayor recepción de PD: Bogotá con el 26.5\% del total; Santa Marta con el 43\%; Sincelejo 39\%; Pasto con el 13.3\%; Cúcuta con el 36.1\%; Bucaramanga con el 11.9\%, Medellín con el 25\%, Cali con el 34.6\%, y Villavicencio con un 38.5\%.

Otro aspecto fundamental que se garantiza desde un enfoque regional de las alternativas es el relacionado con la reconstrucción del tejido social en concordancia con las condiciones identitarias propias de las comunidades desplazadas. Es claro que los flujos de desplazamiento se dan al interior de unas regiones que han sido constituidas a partir de elementos culturales compartidos y desarrollados históricamente sobre la base de determinaciones biofísicas. En este sentido es fundamental limitar el impacto del desarraigo, permitiendo soluciones que no alejen definitivamente a la PD de sus costumbres y raigambre socio - cultural.

Así también, en el caso estricto de la vivienda ofrecida, es importante atender a la identidad cultural, ella define las formas de construcción del hábitat. En este sentido, se deben proporcionar múltiples alternativas de construcción en forma, materiales, tamaño, que superen la estructura rígida
Magdalena, central Andean, Hills of Maria, Piedemonte, Venezuelan border, Banana Zone, Central Pacific and the Ecuadorian zone; particularly the 9 cities that concentrates most of the DP reception: Bogota with 26.5\% of the total; Santa Marta with 43\%; Sincelejo 39\%; Pasto 13.3\%; Cucuta with 36.1\%; Bucaramanga with 11.9\%, Medellin 25\%, Cali with $34.6 \%$, Villavicencio $38.5 \%$.

Another fundamental aspect that is guaranteed from regional approach alternative is related to the reconstruction social weaving according to the displaced community identity conditions. It is clear that the displacement flows it is produced within certain regions' inlands that have been based on historically shared and developed cultural elements on bio-physic based determinations. It is fundamental to control the lack of sense of belonging allowing solutions that do not part DP from their customs and socio-cultural roots.

Also in the strict sense of the housing offered, it is important to take in consideration the cultural identity as it defines the habitat constructions forms, in this sense, multiple constructions alternatives must be provided; shapes, materials, 
de la estandarización ofrecida por el mercado. La población desplazada debe participar en distintos niveles durante todo el proceso de construcción de las alternativas (diseño, planeación, ejecución, evaluación y seguimiento a través de proyectos regionales).

\section{El DeRECHO A LA VIVIENDA Y EL hÁBitAT dignO.}

La restitución del derecho a la vivienda de la población desplazada es por definición el objetivo central de la búsqueda de alternativas en este campo. Sin embargo, la multiplicidad de opciones y alternativas ofrecidas por el Estado ante la inexistencia de definiciones exactas sobre cuáles deben ser las características de las viviendas a las cuales la PD tiene derecho más allá de lo establecido para VIS y VIP, evidencia la necesidad de establecer algunos elementos que deben ser tenidos en cuenta para la construcción de políticas y de soluciones que transformen las condiciones de la PD y contribuyan a resolver la deuda acumulada en nacientes y ya consolidadas ciudades del país.

Como parte de lo que significa una restitución digna se debe entender que el acceso a la vivienda no es una acción puntual donde todo finaliza con el otorgamiento de un crédito o la entrega de una casa o solución habitacional, el acceso hace referencia a un conjunto de componentes que integran la vida de las personas en cualquier tipo de solución y que se desarrollan continuamente durante procesos. En este sentido, el Estado debe garantizar mecanismos size that goes beyond the rigid standardized structure market offered. Displaced population should participate through the different level of the alternative construction processes (design, planning, execution, evaluation and follow up through regional projects).

THE RIGHT TO HOUSING AND DECENT HABITAT.

The displaced population rights of housing restitution it is by definition the main objective of this field's alternative research. Nonetheless the multiple options and alternatives offered by the State confronting the inexistent DP exact housing characteristics definition beyond the established by VIS or VIP shows the need to establish some variables that should be taken in consideration for policies and construction solutions that transform DP conditions and contribute to the accumulated debt in emerging and already consolidated cities in the country.

To fully understand what a decent restitution means, it must be understood that housing access it is not a particular action which ends with the credit granted or the housing solution house given, the access refers to a set of components that are part of people's life in any type of solution and that develops throughout 


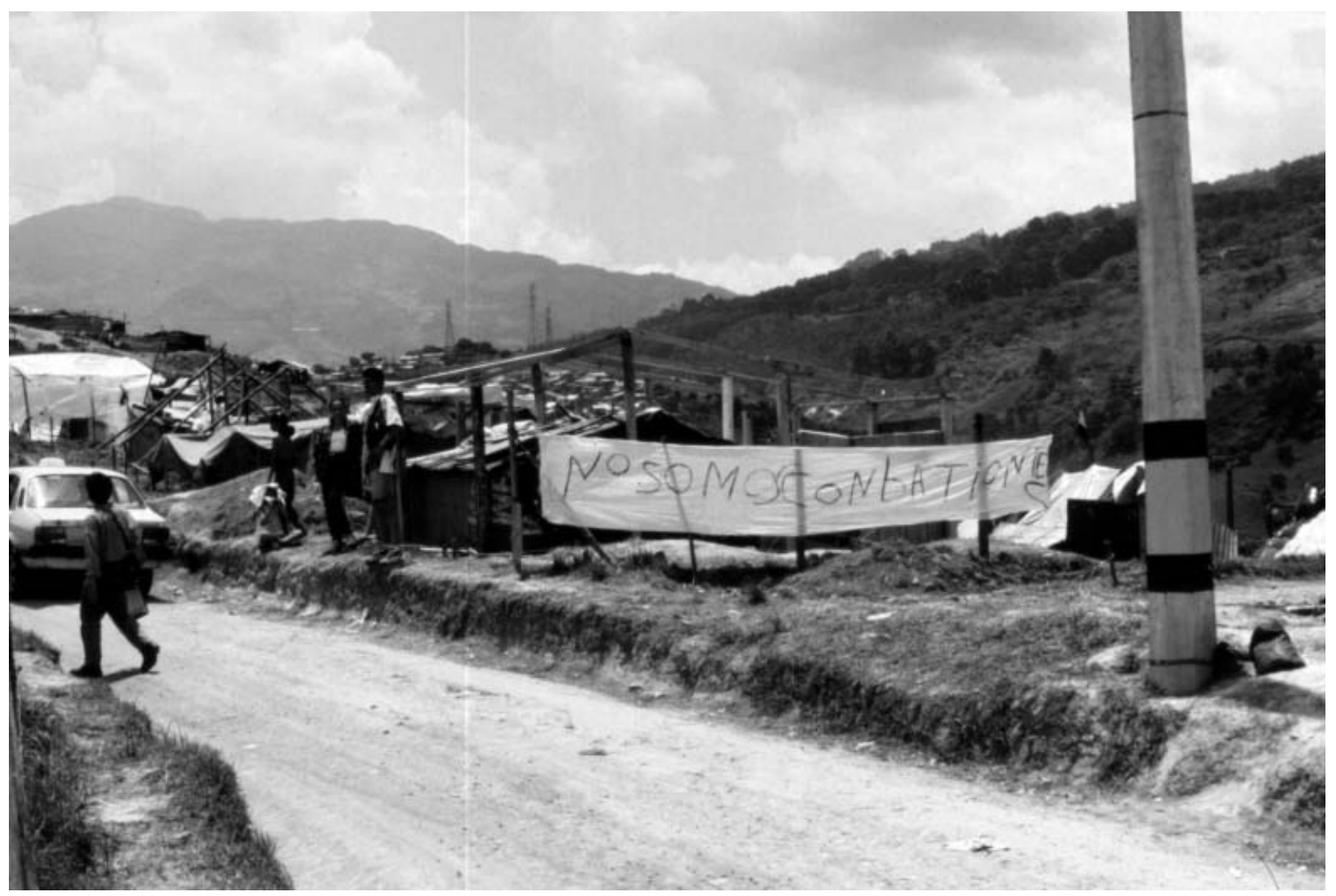

Población desplazada invade en Medellín 2. Los desplazados reivindican el derecho a ser considerados como ciudadanos y ello lo ratifica esta pancarta que indica "NO SOMOS COMBATIENTES", dada la estigmatización existente hacia la población en condición de desplazamiento forzado. Medellín 1998.

Fuente de la Fotografía: Carlos Torres Tovar, 1998.

Displaced population invades Medellin 2. The displaced population claim the right to be considered as citizens as the banner in the picture shows "WE ARE NOT COMBATANT" due to the existing stigmatization to forced displaced population. Medellin 1998.

Photography source: Carlos Torres Tovar, 1998. 
que permitan hacer seguimientos de mediano y largo plazo para atender a las necesidades de la PD en tanto ésta recupera las condiciones para afrontar la vida social autónomamente.

En este mismo sentido es claro que la denominada tenencia segura no es sinónimo de propiedad. No por garantizar un documento o una acción puntual el Estado puede asumir que ha cumplido con el papel de garante de dicho derecho. La propiedad, ya sea individual o colectiva, solamente se restablece cuando es sostenible y para eso es preciso que los habitantes puedan restituir relaciones que les permitan asumir roles productivos a través del restablecimiento del derecho al empleo y la formación, entre otros.

\section{BÁsicos VITALES.}

La propuesta de establecer unos básicos vitales surge de la necesidad de frenar la reducción gradual y constante de los mínimos vitales ${ }^{31}$ en el marco del actual modelo económico de desarrollo.

31 “... se define como aquella parte del ingreso del trabajador que está destinado a solventar sus necesidades básicas y del núcleo familiar dependiente, tales como alimentación, vivienda, salud, educación, recreación, servicios públicos domiciliarios, entre otras prerrogativas que encuentran expresa consagración en la Carta y que además, posibilitan el mantenimiento de la dignidad del individuo como principio fundante del ordenamiento jurídico constitucional" (Art. 1 de la Constitución Política de Colombia, 1991). the process. The State should guarantee mechanism that allow the long term follow-up to assist the DP needs while it recuperates to confront social life by themselves once again.

It is clear that the so called safe tendency is not synonym of property. It can not be presumed that by guaranteed a document or an specific State action it has been fulfilled the guarantor role of such right. The property either of an individual or collective can only be reestablished when it is sustainable and in order to do the inhabitants must be able to restore relationships that allows them to have a productive role through the right to employment, formation among others.

\section{Vital BASIC.}

The proposal establishes vital basics that emerge from the need to stop the vital basic gradual and constant reduction ${ }^{31}$ within the current economic development model framework.

"It is defined as worker's income share that is destined to meet basic needs and the dependant nuclear family such as food, housing health, education recreation, utilities Public services among others; Rights that are specifically granted in the Charter and that also includes the individual's dignity as the constitutional legal order main principle." (Art. 1 de la Constitución Política de Colombia, 1991) ( Colombia's constitution article 1, 1991) 
La vida de las personas en la sociedad actual debe ser desarrollada con las garantías suficientes para satisfacer las necesidades básicas -no mínimasproducidas en cada contexto y territorio. Es decir, no depende del Estado ni mucho menos del mercado establecer la posibilidad de garantizar unos mínimos en relación a criterios como la eficiencia, el recorte y la austeridad, entre otros. Por el contrario, depende de las necesidades de hombres y mujeres y en este caso especial de las de la PD, la configuración de políticas encaminadas a su cumplimiento.

\section{Elementos QUE Integran las alternativas.}

La oferta que se conforme de soluciones habitacionales para la población desplazada debe recoger e incorporar algunos de los resultados obtenidos en la Encuesta Nacional de Verificación (2007), ya que ellos denotan características particulares que no se deberían desconocer al homogenizar toda la oferta que se produce actualmente. Entre otros están:

- La Encuesta señala que el 54,2\% ha sido expulsado de zona rural, el 23,7\% de cabecera municipal y el 21,0\% de centro poblado. Ello implicaría distinguir a partir de este aspecto el tipo de solución a plantear según el origen del desplazamiento.

- El 76,4\% desea permanecer en el lugar actual, el 9,4\% reubicarse o salir del país, y tan sólo
People's life in current society should be with the guarantees to fulfill their basic needs, not minimal ones, produced in each territorial context. It means is beyond the State and even less the market to establish the possibility of a guarantee minimum in relationship to efficiency, cuts, austerity among others; on the contrary depends on women/men in this case in particular DP, the policies the lead to fulfill such right.

\section{Elements that are part OF the alternatives.}

Displaced population housing solutions offered must include and incorporate some of the results given by the National Verification Survey (2007) as it shows the particular characteristics that should not be overlooked homogenizing the total current offer. Some of them are:

- The survey shows that $54.2 \%$ of the people has been expelled from rural zone, $23.7 \%$ from municipal heads and $21.0 \%$ from populated centers. This implies to distinguish according to this aspect, the displacement origin.

- $76.4 \%$ wants to stay where they are, $9.4 \%$ wants to relocate or go out of the country 
el 3,1\% retornar. Ello plantea la necesidad de establecer una oferta urbana que reconozca las potencialidades de la PD y las incorpore en las alternativas que desarrolle.

- La edad promedio es 23,2 años. Los jefes/as y sus cónyuges tienen en promedio 40 años de edad, mientras que el resto tiene en promedio 14 años de edad. Se presenta un alto nivel de analfabetismo cercano al 13,9\%. Ello demanda el reconocimiento de equipamientos y alternativas para los distintos grupos generacionales y etáreos.

- Un 54,3\% de la población desplazada es menor de 20 años, en contraste con un 40,2\% en el caso de la población colombiana. El tamaño de la población joven obliga a construir con mayor claridad alternativas educativas, culturales, de formación y capacitación para la vida.

- Un 3,7\% de la población se auto-reconoce como indígena y un $21,2 \%$ como negra o afrocolombiana. La multiculturalidad y multietnicidad han de ser una alternativa.

- Un 17,5\% de los hogares presenta algún miembro que sufre una discapacidad física o mental. Para ello la vivienda debe cumplir con unas condiciones y estándares básicos que ayuden a mitigar esta situación adicional de vulnerabilidad. and only $3.1 \%$ wants to go back. This poses the need to establish a urban offer that recognizes DP potentials and incorporates in the development alternatives.

- The average age is 23.2. Head of household and their spouses have an average of 40 years old, while the rest is 14 years old. There is a high illiteracy rate, near 13.9\%. This requires different infrastructures for each age and generation demands.

- $54.3 \%$ of the displaced population is under 20 years old, contrasting with the rest of Colombian population with $40.2 \%$. The young population size makes a must to offer educational, cultural and formation and training for life.

- $3.7 \%$ of the population recognizes themselves as indigenous and $21.2 \%$ as black or afro-Colombian. Multiculturalism and multiethnicity must be an alternative too. .

- $17.5 \%$ of households have a member with some kind of mental or physical disability. The housing solution must meet some basic, standard conditions to help this additional vulnerability situation. 
Se requiere construir, entonces, una Matriz de Interpretación que permita reconocer los distintos niveles de temporalidad y tipo de familia en condición de desplazamiento para proveerle una solución adecuada. Ello implica reconocer que se trata de una población diversa y que por tanto requiere de tratamientos diferenciados y no soluciones homogenizantes.

\section{Sobre las alternativas a la Vivienda.}

Se ha de partir por reconocer que la solución no ha de ser sólo una vivienda nueva, sino un abanico de múltiples alternativas que van desde la vivienda con opción de compra -leasing habitacional- hasta la plena propiedad. Ello implica reconocer que este es un proceso que tiene gradualidad en el tiempo.

El diseño de este abanico de posibilidades de solución para el acceso a la vivienda digna para la Población Desplazada, permitirá determinar el tipo de solución para cada hogar o grupo específico dependiendo de varios factores, tales como sus condiciones étnicas y culturales, su situación actual, su tiempo de desplazamiento y el tipo de hogar, entre otras.

Ahora bien, es claro que la realización plena del derecho a la vivienda para la totalidad de la Población Desplazada no puede darse a corto, o incluso a mediano plazo. Siendo por tanto necesario diseñar distintas alternativas para solucionar la precaria situación habitacional del desplazado,
An Interpretation Matrix must be made that would allow recognizing the different temporal levels and type offamilies in displaced conditions to provide them with the adequate answer. This implies to acknowledge the fact that is a diverse population so it requires different treatment and not homogeneous answers.

\section{Housing ALTERNATIVES.}

The starting point must be the that not only a new housing is needed, though also a myriad of alternatives that goes from housing to buying -housing leasing- to full property ownership. This implies that it is a gradual process in time.

The design of this myriad of possible solutions to decent housing access for Displaced Population will allow determining the type of solution for each household or specific group depending on various factors such as ethnic and cultural conditions, current situation, displacement length, type of household among others.

It is clear that full creation of rights of housing to the whole Displaced Population it can not be done in short term, but in the long term. So it is necessary to design different alternatives to solve the displaced precarious 
analizando distintas formas de tenencia segura que puedan irse asegurando, siempre con la perspectiva de convertirlas en soluciones de largo plazo con capacidad de ser sostenibles.

También es necesario reconocer que la política de vivienda ha sido fundamentalmente orientada hacia la generación de vivienda nueva y aunque se han planteado otras alternativas, éstas no se han fomentado. Entre las soluciones a observar como alternativas a la vivienda para la población desplazada se enumeran las siguientes posibilidades, sin que éstas se constituyan en las únicas posibles:

- Adquisición de vivienda nueva.

- Adquisición de vivienda usada (frente al acceso a una vivienda usada se requiere de un peritazgo más flexible para su valoración -ello implica acciones de mejoramiento de vivienda y mejoramiento barrial-).

- Construcción en sitio -lote o parcela- propio (implica que el desplazado ya cuenta con suelo urbanizable).

- Mejoramiento de vivienda actual (se presentan casos en los cuales la población desplazada satisfizo por su propio esfuerzo el acceso a una vivienda, pero ella requiere ser mejorada y adecuada). housing situation; analyzing different safe tendency forms that can be ensured that can become a sustainable long term solution.

It is also necessary to recognize the housing policies have mainly been oriented to new housing generation and although other alternatives have been planned, these ones have not been fostered to be real ones. As the displaced population housing alternative solutions are mentioned the following ones, not being the only possible ones either.

- New housing acquisition

- Old housing acquisition (old housing access requires a more flexible expert's report for its value -this implies housing and neighborhood improvement-)

- Ownership of construction site -plot or lot- (it implies that the displace already has land where to build)

- Current housing improvement, (there are cases where the displaced population out of their own effort has been able to have housing access, but it requires improvements and adequately remodel for their needs) 
- Adecuación de asentamientos de origen informal (implica la legalización de títulos, mejoramiento de entorno y vivienda, provisión de infraestructura y equipamientos adecuados, etc.).

- Propiedad colectiva de la vivienda (es necesario pensar en formas de propiedad colectiva poco comunes en Colombia -vivienda reciclable en función del retorno-).

- Reciclaje de estructuras urbanas para vivienda. Sería posible diseñar programas de reciclaje de estructuras urbanas para vivienda mediante la adquisición y readecuación de edificios abandonados y vivienda usada que estén aptos estructuralmente. Ya sea para vivienda nueva o vivienda en alquiler, considerando distintas opciones de tenencia (propiedad colectiva, arriendo de largo plazo y arriendo con opción de compra, entre otros, para que algunos grupos de población desplazada encuentren albergue temporal en tanto acceden a una vivienda definitiva).

- Vivienda agro productiva en los bordes urbanos y áreas rururbanas (suelos de expansión). Con el desarrollo de proyectos agroforestales, guardabosques, entre otros.

- Diseño de asentamientos humanos rurales.
- Informal settlement origin ad equation (it implies property deed legalization, housing and surrounding improvement, adequate infrastructure and utilities, etc.).

- Collective housing ownership, (it is necessary to think in collective ownership not common in Colombia-recycle housing in case of returning-).

- Urban structure recycling. It could be possible to create housing urban structures recycling programs through acquisition an old abandon building and houses collection that are structurally fit, either new or rented housing taking in consideration different tendencies options (collective property, long term renting, leasing among others so some displaced population groups find temporal shelter while they access to a definite solution).

- Agro-productive housing at urban edge and "rururban", (areas that although are rural, have urban influence that in time becomes part of the city's expansion land) with agroforestry projects development, rangers among others.

- Rural settlement designed 
Asímismo, en el diseño y concepción de las alternativas de vivienda para la población desplazada ha de tenerse en consideración el concepto de vivienda productiva, ya que esta no cumple una función única de dormitorio o lugar de alojamiento. Ello ratifica el hecho de que la vivienda es entendida y apropiada como solución a una necesidad y no una mercancía que se configura para ser comercializada.

Se hace también indispensable configurar otras iniciativas que contribuyan a brindar soluciones de vivienda para la población desplazada. Algunas de estas se señalan a continuación:

- Gestión de suelo urbanizable. Si bien existen restricciones en la disponibilidad del suelo urbano en las grandes ciudades colombianas, se hace necesario garantizar la gestión de suelo urbanizable nuevo para vivienda social y en este caso particular para desarrollar soluciones habitacionales para la población desplazada. Hasta ahora los Planes de Ordenamiento Territorial -POT-, ordenados por la Ley 388 de $1997^{32}$, invisibilizan la problemática del desplazamiento forzado y con ella las problemáticas del hábitat y la vivienda.

- Convergencia de recursos y programas. Se requiere garantizar la convergencia de recursos

32 Conocida como Ley de Desarrollo Territorial o la Ley de los Planes de Ordenamiento Territorial, vigente desde 1997.
Displaced population housing alternatives design and conception must include the productive housing concept as it is not only a lodging place. This stresses the fact that housing is not only understood and appropriate to a need and not merchandise to be commercialized.

It is also important to create other alternatives that contribute to displaced population housing solutions as the ones now mentioned:

- Possible to urbanize land. Although there are restrictions in the urban land available in big cities in Colombia, it is necessary to manage the possible to urbanize land for social housing and in this particular case develop housing solutions for displaced population. Up to now the Territorial Regulation Plans -POT- regulated by Law 388, 199732 views the forced displacement problem and with it housing and habitat problems.

- Resources and programs convergence. It is required to guarantee the different public

32 Known as the Law of Territorial Development or Law of Territorial Regulation in force since1997. 
y programas de las distintas instituciones públicas en materia de vivienda en los diferentes órdenes (nacional, departamental y municipal, como lo es el caso de los recursos que para tal fin destina el Instituto Colombiano de Bienestar Familiar -ICBF-).

\section{FinanCiación.}

El tema de la financiación es tal vez el más complejo, ya que el acceso a una vivienda social -VIS o VIPdepende hoy día exclusivamente de los recursos monetarios disponibles para su adquisición. Sin embargo, los recursos nacionales destinados a dar soluciones a la vivienda para la población desplazada han sido limitados frente al tamaño de las necesidades. Sumado a esto se presentan serias dificultades para complementar los recursos del subsidio a la vivienda direccionado por el gobierno nacional.

La política nacional sigue estableciendo que los recursos de subsidio para acceso a soluciones de vivienda dependerán de la misma bolsa de recursos $^{33}$ que tiene el resto de colombianos,

33 Corresponde al Ministerio de Ambiente, Vivienda y Desarrollo Territorial -MAVDT- el impulso y desarrollo de la política nacional de vivienda y el apalancamiento de los recursos económicos para el otorgamiento de subsidios para su adquisición, los cuales convergen al Fondo Nacional de Vivienda -FONVIVIENDA(Decreto 555 de 2003), quien los administra, siendo las Cajas de Compensación Familiar las que los asignan a nivel nacional. institution housing resources and programs converge in the different levels - national, departmental, and municipal as it is the funds that the Instituto Colombiano de Bienestar Familiar -ICBF-. (Colombian Institute of Family Welfare)

\section{Financing.}

The financing issue is more complex as the social housing -VIS or VIP- access depends nowadays exclusively to the available money resources for its acquisition; nonetheless, the national resources destined to solve the displaced population housing needs are limited in relation to the need, added to the fact that there are serious problems to complement the national government housing subsidies.

The national policy still establishes that the subsidies resources to housing solution access will depend on the same bag of resources ${ }^{33}$ that the rest of the Colombian people have

33 It is the Ministerio de Ambiente, Vivienda y Desarrollo Territorial -MAVDT- (Ministry of Environment, Housing and Territorial Development) responsibility to foster and develop national housing policy and facilitate the economic resources for housing subsidies granting which converge in the Fondo Nacional de Vivienda -FONVIVIENDA- (National Housing Fund) Decree 555, 2003 that are manage by the Family Compensation financial institution (Cajas de Compensación Familiar) that assign them at national level. 
lo cual no contribuye en la solución de la problemática nacional de vivienda y menos aún de la población desplazada. Ello se ratifica al observar las indicaciones contenidas en el Plan Nacional de Desarrollo 2006 - 2010, que señala y da el mismo tratamiento a los hogares de población desplazada que a los que presentan extrema pobreza,

"Esquema para hogares vulnerables: desplazados y en extrema pobreza. Los hogares de más bajos ingresos serán vinculados a la Red de Protección Social para la superación de la Pobreza Extrema ${ }^{34}$, mediante la implementación y financiamiento de soluciones acordes para este segmento de la población como el arrendamiento, vivienda usada y mejoramiento. Conforme a lo anterior, el Ministerio de Ambiente, Vivienda y Desarrollo Territorial -MAVDT- y los demás ejecutores de la política de vivienda, tendrán en cuenta la población objetivo de la Red en el momento de distribuir y asignar los recursos destinados a los tipos de soluciones señaladas anteriormente. Asímismo, se promoverá una mayor participación de los municipios y departamentos en la atención de la población desplazada, mediante la asignación de subsidios y/o el acompañamiento en la ejecución de los recursos del Gobierno Nacional." ${ }^{35}$

En este sentido, “( ... la reparación material no puede tener un carácter simbólico y episódico, cuando la mayor parte de los desplazados son colombianos $y$ which is not a solution to the national housing problem, even less for the displaced population. This ratifies as it is revised the National Development Plan 2006-2010 which gives the same treatment to extreme poverty and forced displaced population.

Vulnerable household scheme: displaced and under extreme poverty. The lowest income households will be linked to Social Protection Network to overcome Extreme poverty ${ }^{34}$ through implementation and financing solutions according to the population segment as renting, old housing and improvement. Related to the above mentioned the Ministry of Environment, Housing and Territorial Development -MAVDT- and the rest of the housing policies executors will keep in mind the population targeted with the Network when the resources are distributed and assigned destined to the type of solutions above mentioned. It also should promote a greater municipal and departmental participation in relation to the displaced population through subsidies assigned and/or National Government resources' execution follow-up." 35

"(...) the material reparation can not be a symbolic and in episodes as most of the

\footnotetext{
34 CONPES Social 102. 2006.

35 DNP. 2007. p.192.
}

34 CONPES Social 102. 2006

35 DNP. 2007. Pág.192. 
colombianas sometidos estructuralmente a una crisis social." ${ }^{\text {36 }}$

No es admisible que mientras la población desplazada no puede acceder a una vivienda digna, una magnitud importante de los recursos asignados permanezca en manos de las entidades financieras, quienes a su vez le niegan la posibilidad de acceso al crédito hipotecario a la población desplazada por el no cumplimiento de los requisitos mínimos exigidos.

En esta perspectiva se hace necesario pensar en las lógicas y fuentes de financiación para poder adelantar de manera masiva y no "gota a gota", mediante la política de focalización, el derecho a una vivienda digna de toda la población desplazada.

En este mismo sentido es necesario que se asuma un carácter redistributivo de los recursos, como única manera de apalancar procesos de larga duración con capacidad de impactar estructuralmente la dinámica productiva y de atención a la población vulnerable. La estrategia financiera ha de establecer una combinación de fuentes, impuestos y crédito, entre los que se proponen:

\section{CoRresponsabiLIDAD MUNICIPAL Y TERRITORIAL.}

El aporte de recursos municipales y territoriales que contribuyan a solucionar el problema de la vivienda

36 ROMERO, Marco. 2007. Pág. 21.

72 revista invi № 66 / Agosto 2009 / Volumen № 24: 17-86 displaced population are Colombian people in a structural social crisis." 36

It is not admissible that as long as the displace population can not access to a decent housing, a great magnitude of the assigned resources belong to the financial institutions, which deny mortgage to the displaced population due to the impossibility to meet the minimal requirements.

Under this perspective is necessary to think in logical financing sources to be able to solve the problem massively and not "drop by drop" through a focalization policy for the displaced population right of housing.

It is also necessary the resources redistribution as the only way to facilitate the long term process to really impact the structural production dynamic and vulnerable population needs attention capacity. The financial strategy must establish a combination of sources, taxes and credit among the possible ones.

Municipal ANd teRRITORIAL CO-RESPONSIBILITY.

Municipal and territorial resources contribution to solve the housing problem

36 ROMERO, Marco. 2007. p. 21.

ARTICLE: Housing for displaced population in Colombia. Public policy and law enforcement Recommendations / Carlos Alberto Torres Tovar, Johanna Eloísa Vargas Moreno. 
para la población desplazada, con muy contadas excepciones, ha sido prácticamente inexistente. Tal vez es preciso reconocer los esfuerzos de ciudades como Bogotá y Medellín en los últimos años.

Sin embargo, es necesario establecer los niveles de corresponsabilidad de los municipios expulsores (por la riqueza) y exigir de ellos que parte de los recursos que la Nación le aporta por vía de transferencias o regalías contribuyan en la solución de la problemática, así como también se estimule y premie a las comunidades receptoras. Dicho de otra manera, debe tenerse en cuenta el tema de distribución de los "beneficios" (para los municipios expulsores) y de los "costos" (para los municipios receptores) del desplazamiento en términos de presupuesto disponible.

De igual modo si no es posible otorgar subsidios monetarios, el aporte de los entes territoriales podría ser en especie (suelo, redes e infraestructura, conexiones a servicios públicos domiciliarios, equipamientos colectivos, provisión de servicios sociales, etc.).

Asímismo, es necesario garantizar que los municipios apalanquen recursos complementarios para completar el valor de la vivienda a subsidiar (50 a 70 Salarios Mínimos Mensuales Legales Vigentes -Smmlv-), reconociendo la compra de mejoras o mediante la implementación de un subsidio municipal para atención a la población for the displaced population, with countable exceptions, has been mostly inexistent. Maybe it must be necessary to recognize Bogota and Medellin Cities' efforts the last few years.

Notwithstanding, it is necessary to establish correspondence levels with the expeller municipalities by it wealth and demand that they supply part of the resources that the Nation supplies by means of transference or royalties to contribute to the problem solution as well to stimulate and reward the recipient communities. In another words it must be taken in consideration the "benefits" distribution issue for the expeller municipalities and the "expenses" for the recipient municipalities of the displaced in terms of available budget.

If it is not possible monetary subsidies the territorial entities contribution can be an alternative (land, networks and infrastructure, utilities public services and connections, collective amenities, social services provision, etc)

It is necessary to guarantee the municipalities facilitate complementary resources to complete the subsidized housing value (50 to 70 current minimum legal monthly wage -Smmly-) recognizing the improvement buy or through municipal subsidies implementation 
desplazada como lo han establecido ciudades como Medellín y Bogotá.

\section{IMPUESTO DEL 4 X 1000 PARA LA PAZ.}

En noviembre del año 1998, el gobierno nacional, amparado en las facultades que otorga la Constitución en los momentos de crisis económica, creó una contribución especial sin precedentes en la historia fiscal de Colombia. Esta contribución gravaba con una tarifa del $2 \times 1000$ a las transacciones financieras que implicaban el retiro de fondos de las cuentas corrientes y de ahorro de bancos y otro tipo de intermediarios. Señalan Ignacio Lozano E. y Jorge Ramos F. que,

"(...) Inicialmente el gobierno anunció que el nuevo gravamen sería transitorio y que su aplicación se extendería hasta el 31 de diciembre de 1999, una vez se hubiesen corregido los problemas más graves que enfrenta el sector financiero. No obstante, el surgimiento de algunos imprevistos, como el terremoto en el eje cafetero, llevó a modificar la decisión inicial, ampliando el período de aplicación del impuesto hasta finales del año 2000."37

Sin embargo, entre los acuerdos que firmó el gobierno nacional con el Fondo Monetario Internacional -FMI- se contempló, entre otras cosas, un riguroso programa de ajuste fiscal, que toca tanto los gastos como los impuestos. Así, dentro de las reformas tributarias presentadas los

37 LOZANO, Ignacio; RAMOS, Jorge. 2000. Pág. 1.

74 revista invi №66 / Agosto 2009 / Volumen № 24: 17-86 to support the displaced population as Medellin and Bogota have established.

\section{$4 \times 1000$ TAX FOR PEACE.}

In November 1998 the national government supported by the Constitution faculties in a crisis moment created a especial contribution with no fiscal historical background in Colombia. This contribution taxed for a $2 \times 1000$ rate for financial transactions which implied funds withdrawal from bank and savings accounts and other type of intermediary. Ignacio Lozano E. y Jorge Ramos F said:

"(...) initially the government announced a new provisional taxation and its application would not go beyond December 31 1999 , once the gravest problems that the financial sector was undergoing hadbeen corrected. Notwithstanding, some unexpected events such as the earthquake in the coffee-growing axis led to modify the initial decision, extending the taxation application period to the end of 2000." 37

Nevertheless the agreements signed by the national government with the Internal Monetary Fund IMF included a rigorous fiscal adjustment program that affected the

37 LOZANO, Ignacio; RAMOS, Jorge. 2000. p. 1 
años siguientes figura como pieza fundamental la extensión del impuesto del 2x1000 que ya para el año 2009 está en el 4x1000, convirtiéndose en un impuesto permanente para atender los desfases de las pérdidas de los privados y no como una alternativa de recaudo colectivo para atender las necesidades de los sectores de población más vulnerables en nuestro país, entre ellos la población desplazada ${ }^{38}$.

La propuesta plantea la utilización de este impuesto como una contribución colectiva de toda la sociedad colombiana para ayudar a resarcir los daños provocados por el desplazamiento forzado en nuestro país y particularmente aportar los recursos para atender las soluciones habitacionales que se requieren. Es decir, que este impuesto se convierta en un impuesto para la paz y no para la guerra en Colombia.

\section{BieneS deL NARCOTRÁfICO Y REPARACIÓN.}

El Decreto 42 de 1990, otorga facultades al Consejo Nacional de Estupefacientes para la administración y disposición de los bienes vinculados directa o indirectamente o provenientes del narcotráfico. Este Consejo tiene a su vez la responsabilidad en la formulación de las políticas y programas en materia de lucha contra la producción, tráfico

38 El monto transferido por el estado de la recaudación del 4x1000 en el año 1999 asciende a 24.6 billones de pesos (12.300 millones de dólares). expending as well as the taxes. So, within the tax system reforms introduced the following years it was key the extension of the $2 \times 1000$ tax that by 2009 is $4 \times 1000$ turning into a permanent tax to address the private sector losses gaps not like an alternative to collective tax collection to tackle the most vulnerable population needs in our country within them, the displaced population. ${ }^{38}$.

The proposals suggest the use of this tax as a collective contribution to the whole Colombian society to help restore the damages provoked by forced displacement in our country and particularly to provide resources to solve the housing solutions required to address the problem, in other words that this tax becomes a tax for peace and not for war in Colombia.

\section{Narco-trafFic goods and RePare.}

Decree 42, 1990 grants the National Narcotic Council faculties to manage and have for their disposal properties directly or indirectly linked to narco-traffic. This Council has the responsibility in the combat policies and programs formulation against

38 Transferred amount by the State $4 \times 1000$ taxation in 1999 is of 24.6 billons de pesos (12,300 millions dollars). 
y uso de drogas que producen dependencia, y la administración de bienes objeto de extinción de dominio.

En ese sentido, se hace necesario establecer que parte de los recursos incautados al narcotráfico también han de contribuir a fondear los recursos que se requieren para construir la paz, ya que gran parte de la población desplazada también lo ha sido por el aprovechamiento indiscriminado del narcotráfico de los territorios rurales para la siembra de algunos psicoactivos (marihuana, coca, amapola).

\section{Estrato $0^{39}$.}

La persona al tener una vivienda formal automáticamente cambia de estratificación y ello hace que se pierdan o reduzcan los subsidios que el Estado le otorga en materia de tarifas para los servicios públicos domiciliarios, el acceso al sistema de salud subsidiado a través de la encuesta $\mathrm{SISBEN}^{40}$, etc. Asímismo, los vuelve sujetos de DERECHOS en tanto DEBERES y ello significa

39 La estratificación socioeconómica en Colombia clasifica a la población en rangos de 1 a 6 , siendo uno el más deficitario y seis el de mayor poder adquisitivo. El estrato 00 sin estrato corresponde a una categoría para diferenciar sectores en condiciones especiales. La estratificación se utiliza para el cobro de tarifas de servicios públicos, tasas impositivas, acceso a bienes y servicios colectivos como la salud y la educación, así como para la asignación de subsidios.

40 Sistema de identificación de potenciales beneficiarios de programas sociales. DNP (1995). Documento CONPES Social 40.

76 revista invi № 66 / Agosto 2009 / Volumen № 24: 17-86 production, trafficking and use of drugs that produce dependency, and property subject to forfeiture.

It is necessary then to establish part of the confiscated resources to fund what it is required for building peace which most of the displaced population has also been through, because of the narco-trafficking rural territory indiscriminate usage for psychotropic sow (marihuana, coca and poppy).

\section{Stratum $0^{39}$}

People immediately changes status when acquires a property and that means they lose or reduce the State subsidies in terms of the utilities public services rate, health access subsidies through the SISBEN survey ${ }^{40}$, etc as well as becomes subject to RIGHTS as well as DUTIES and that means utilities public services connections; property tax,

39 The socio economic stratum in Colombia classifies population in ranges of 1 to 6 , (being 1 the most deficit and 6 the ones with the most .purchasing power. The 0 stratum or without stratum; belongs to a category to differentiate people, who have special conditions. The stratification is to be used for public services rate, taxes, collective property and services access such as health and education, as well as for subsidies assignation.

40 Sistema de identificación de potenciales beneficiarios de programas sociales. DNP (1995). Documento CONPES Social 40. 
tributar en materia de conexiones a servicios públicos domiciliarios, pago de tasa contributivas como el impuesto Predial, los impuestos de Valorización (local o general) y tarifas por el acceso a servicios sociales, entre otros.

En cualquiera de las opciones de acceso a la vivienda para la población desplazada, debe tenerse en cuenta que la transformación de "no propietario urbano" a propietario pleno, implica incurrir en los "costos de la formalidad", los cuales pueden impedir que se mantenga la propiedad y el pleno goce del derecho a una vivienda digna. Por ello se propone que en el proceso de formalización se establezca un periodo de transición, considerando a los nuevos propietarios, por un tiempo (cinco años mínimo) como Estrato 0, generando un proceso progresivo en el tiempo que les permita asumir los costos asociados a la formalidad.

\section{Otros APORTANTES.}

Se deben buscar otros aportes más allá de los recursos que debe disponer el Estado Colombiano. Estos aportes deben provenir de diversas fuentes, cabe señalar las siguientes:

- Bolsa de recursos internacionales de la Unión Europea, Estados Unidos y Japón, entre otros.

- Donaciones nacionales e internacionales directas mediante la producción de viviendas por sectores privados, ONG, agencias de cooperación, entre otras. assessment (local or general) taxes, social services access rates, etc.

Displaced population housing access must be taken in consideration in any of the options as becoming "no urban proprietor" to full ownership implies "formality expenses" which can not be the reason to acquire the property and full right to housing, that is why it was proposed that during the formalization process a transition period is established, granting the new proprietors time (5 years minimum) as 0 Stratum generating a progressive process in time that would allow them to cover the expenses linked to formality.

Other CONTRibutions.

Other contributions must be found beyond Colombian States' resources. These contributions should come from different sources such as:

- International resources bag (EU, US and Japan, etc).

- Direct national and international donations through private sector, NGO, cooperation agencies housing production. 
- Créditos de largo plazo con tasas de interés bajas o "cero intereses" como aportes de la Comunidad Internacional y de las entidades multilaterales.

- Donaciones del Banco Mundial, del Banco Interamericano de Desarrollo, del Banco Alemán KfW, entre otros.

\section{LOS SUBSIDIOS.}

El hecho de que la política de vivienda esté basada en el otorgamiento de un subsidio a la demanda, en lugar de en un subsidio a la oferta, condiciona esta última a los ciclos económicos de la construcción. Ello conlleva a que en épocas de auge económico la denominada industria de la construcción se incline por el desarrollo de viviendas de alto precio para los estratos socioeconómicos más altos que le generan mayor rentabilidad por unidad de vivienda, en detrimento de la demanda persistente y creciente de Vivienda Social -VIS y VIP-.

Por tanto, es necesario diseñar y poner en práctica mecanismos más objetivos para la asignación de ayudas para vivienda, que reconozcan la diferencia entre ser un pobre urbano y un poblador desplazado, configurando tratamientos diferenciados.

\section{Un Operador Nacional.}

En la actualidad la asignación de los subsidios para la VIS o la VIP se efectúa por parte de FONVIVIENDA a través de las Cajas de Compensación Familiar.
- Long term credits with low interest or "0 interest" as International Community and multilateral entities support.

- World Bank, BID, German Bank KfW, etc donations.

\section{Subsidies.}

The fact that the housing policy is based on demand subsidies granting instead of offered subsidies conditions, this last one depends on the construction economy cycles. This leads to the demand's decrease in healthy economy times as the construction industry inclines to high prices housing as they generate the highest return per housing unit reducing the social housing -VIS and VIP-production.

It is important to design more objective housing funds assignation mechanism that recognize the difference between urban poverty and displaced one configuring different treatments.

\section{A National Operator.}

VIS or VIP subsidies assignation nowadays is done by FONIVIVIENDA through Family Compensation Institutions, (Cajas de Compensación Familiar). Housing production 
La producción de las viviendas es de entera responsabilidad e iniciativa del mercado y por tanto no existe un Operador Único que atienda todos los aspectos del acceso a la vivienda desde su financiación, su producción y el seguimiento al consumo de la misma.

\section{LA SOSTENIBILIDAD DE LA VIVIENDA.}

Antes del fenómeno del desplazamiento esta población tenía resuelta, de una u otra manera, su situación en materia de vivienda (como propietario, poseedor $u$ otras formas), por lo cual no puede tener una respuesta igual a la de la población urbana pobre vulnerable receptora, entrando a competir por un mismo subsidio.

Igualmente las condiciones de sostenibilidad ligadas a la producción de los elementos necesarios para la subsistencia del grupo familiar en la mayoría de los casos estaban resueltas. Caso contrario a lo que le sucede al convertirse en un habitante urbano más. Por la situación en la que se encontraban antes del desplazamiento, y ante la carga de responsabilidad del Estado en el fenómeno, es razonable pensar que la realización del derecho a la vivienda para la PD se da a través de la propiedad.

"Si no es posible lograr el retorno de la población en condiciones de seguridad, dignidad y voluntariedad, y si no es posible otorgar la reparación adecuada por los bienes perdidos o abandonados, debe buscarse it is entirely market initiative and responsibility so One Unique Operator does not exist that can deal with all the aspect to housing access from financing, production to its used follow-up.

\section{Housing SUSTAINABILITY.}

Before displacement population phenomenon this population had solved one way or another, the housing situation (as proprietor, owner, or other ways), so it can not be the same answer for poor vulnerable urban population recipient competing in the same terms for the same subsidy.

The sustainability conditions linked to the necessary elements production for the family group survival was previously solved in most cases; something that completely changes when they become another urban inhabitant because of its previous situation before they were displaced and the States responsibility in the phenomenon. It is reasonable to think DP has the right of housing through property ownership.

"If it is not possible for the population to return in proper safety, decent, and voluntary conditions, and $t$ is not possible to grant the proper reparation for the loss or abandon properties and goods,; it should 
entonces que todos los hogares desplazados puedan habitar una vivienda propia y digna en los municipios receptores".

Los autores be then be given to all displaced population household a decent, owned housing in the recipient municipalities."

The authors

\section{A manera de conclusiones y avances: incidencia de las alternativas en la política pública}

Las consideraciones expuestas en este documento se han realizado bajo la convicción de la necesidad inaplazable de producir herramientas útiles para la dignificación de la vida de la población desplazada y en general de la totalidad de la población colombiana, en el marco de la revisión del Estado de Cosas Institucional -ECI-. En este marco la garantía de un hábitat y una vivienda digna en donde poder desarrollar la vida a plenitud, se convierte en una premisa fundamental en cualquier proceso de reparación y restablecimiento de derechos.

Así, la dinámica para la evaluación efectiva de los aspectos constitutivos del ECI, desde el año 2004, frente al tema de la vivienda, permitió la recolección y sistematización de información, así como la formulación de alternativas orientadas a dar razón de esta problemática en Colombia, con énfasis en la situación de la PD. Es así como en la

\section{Conclusions and advances: alternatives impact in public policy}

What was said in this article have been made under the conviction of the urgent need to produce the necessary tools to give a decent life for displaced population and in general the whole Colombian people within the Current Institutional States of Affairs (Estado de Cosas Institucional -ECI-.). A decent habitat and housing guarantee in this framework where life can be fully lived will become the main premise in any reparation and rights reestablishing process.

This way the effective assessment aspect dynamic part of the ECI from 2004 related to the housing issue has allowed information recollection and systematization as well as alternatives formulation guided to address this problem in Colombia emphasizing DP situation as well as investigating the causes 
indagación de causas y en la búsqueda de soluciones y alternativas de política pública de vivienda para $\mathrm{PD}$ es necesario incorporar la discusión sobre el tema del ordenamiento territorial, como un eje de entrada y análisis esencial para comprender las dimensiones y alcances de dicha problemática.

Por ello, la Corte Constitucional, después de revisar el seguimiento al cumplimiento de la Sentencia T-025 de 2004, expidió en enero del presente año el Auto $\mathrm{N}^{\circ}$ 008, donde se señala que,

"Tanto el informe del Gobierno Nacional como el de la Comisión de Seguimiento mostraron importantes rezagos en materia de vivienda, tierras y generación de ingresos. En el informe del Gobierno, en materia de vivienda, sólo $23 \%$ de los hogares gozan de seguridad jurídica de la tenencia, 35\% vivían en condiciones de hacinamiento y $53 \%$ tiene acceso a todos los servicios públicos. (...) Según el informe de la Comisión de Seguimiento, en materia de vivienda sólo el 5\% de los hogares del RUPD cumple con las condiciones de vivienda digna. Para la población no registrada, se tiene un porcentaje un poco mayor $(7 \%) .{ }^{.41}$

Frente a ello, la Corte Constitucional caracteriza las líneas de política pública que en adelante deben ser asumidas por el Estado para la superación de dicho Estado de Cosas Inconstitucional, junto con

41 Auto $\mathrm{N}^{\circ} 008$ de 2009 de la Corte Constitucional. and solutions; displaced population housing public policies alternatives which should include the territorial regulation issue as starting point axis and analysis, especially to understand this problem dimensions and reach.

The Constitutional Court after revising the follow-up of ruling T-025, 2004 ruled in January of this year Decree No 008 in which says:

"The National Government report and the Follow-up Commission showed important deficit in housing, land and income generation issues. The Government report related to housing states that only 23\% of the households exercise legal security possession, 35\% lived in overcrowded conditions and 53\% have access to all public services. (...) According to the Followup Commission report related to housing issues says only $5 \%$ of the RUDP households meets the decent housing conditions. For the unregistered population it has a little bit higher percentage (7\%)." ${ }^{\prime 1}$

Constitutional Court characterizes the public policies guidelines that should include the State from now on for the overcoming of the Institutional States of Affairs together with

41 Constitutional Court Law N No08, 2009. 
los tiempos para que éste se concrete. Indicando que,

“(...) (i) los componentes de la política deben ser replanteados en su totalidad no sólo por el gran rezago mostrado, sino porque su diseño actual amenaza con perpetuar el estado de cosas inconstitucional (...). En el primer grupo se encuentran los componentes de vivienda, generación de ingresos y tierras." ${ }^{.42}$

Dentro de las recomendaciones consignadas en el Auto se ordena la reformulación absoluta de la política pública ${ }^{43}$, proceso que debe culminar el 30 de junio de 2009 y que debe implementarse a partir del 31 de agosto de 2009.

Como se expresó durante el documento, la política de vivienda con que cuenta Colombia no se corresponde con las dimensiones de las necesidades de sus pobladores y, por el contrario, mantiene una tendencia hacia la agudización de su problemática. En este sentido, las recomendaciones presentadas por la Corte Constitucional deben ser atendidas indistintamente del tipo de población que se haga beneficiaria.

42 Ibíd.

43 Los criterios que deben ser tenidos en cuenta en este proceso son: proveer el acceso a alojamiento y a viviendas básicas; proveer apoyo para el auto sostenimiento; garantizar el goce efectivo de todos los derechos a la PD; definir el compromiso de las entidades territoriales con la PD, en especial en los POT y usos del suelo; estimular la oferta para desplazados; garantizar el enfoque diferencial; dar prioridad a madres cabeza de familia; ordenar medidas transitorias que garanticen la sostenibilidad; cumplimiento de los mínimos de racionalidad de las políticas públicas, señalados por la Corte Constitucional. the time it should take to become a reality saying that:

"(...) (i) the policy elements should be completely reconsidered, not only because of the lagging but also because it can perpetuate the current institutional states of affairs (...). The first group has housing, income generation and land components. ${ }^{42}$

The recommendations ruled in the Decree rules the complete reformulation of the public policy ${ }^{43}$ process that should be finished by June $30^{\text {th }} 2009$ and implemented by August 31 $1^{\text {st }} 2009$.

As it was said through out this article the housing policy which Colombia has it does not correspond to the population needs on the contrarykeepsatendency toworsen the problem. The Constitutional Court recommendations can be taken in consideration to any kind of population which benefits from it.

42 Ibíd.

43 The criteria that should be taken in consideration in this process: Lodging and basic housing access; provide help for self support; guarantees the full exercise of the DP rights; territorial entities commitment with the DP, especially in the POT land usage; displacement offer stipulation; guarantee the differential approach; give priority to mother head of households; sustainability guarantee of temporary measures ruling; meet the minimum rational public policies observance by the Constitutional Court. 
En este mismo sentido se afirma que en Colombia no ha existido una política pública de vivienda y asentamientos humanos, ya sea de carácter rural o urbano. Sumado a la aguda concentración de la tierra y las concesiones al sector privado y el mercado han cerrado las puertas del derecho a la vivienda no solamente a la PD, sino a las mayorías pobres. En este sentido, el Estado colombiano le debe al país políticas efectivas y dignificantes y hoy más allá de la PD la imposibilidad de acceder al derecho a la vivienda es una realidad de muchos colombianos.

Los elementos aquí señalados por el Auto No 008 de 2009 representan un avance significativo en los procesos de exigibilidad de los derechos para la población desplazada y a la vez garantizan ser una puerta de entrada para la concreción del derecho a la vivienda y hábitat digno de todas y todos los pobladores del territorio nacional.

Asímismo, el énfasis en la responsabilidad de las entidades territoriales, con especial atención en los POT y los usos del suelo, es un paso adelante en la orientación de políticas de planeación y ordenamiento territorial a partir de las necesidades del conjunto de la población, lo cual garantiza los límites necesarios a la incidencia del mercado de tierras, el inmobiliario y de la construcción en la definición del modelo de ciudad, región y país para el caso colombiano.
It also says that Colombia has not had any housing and human settlement public policy, either of rural or urban character. Adding to the acute land concentration and the concessions to the private sector and the market has closed the doors to the right of housing not only to the DP but also to most poor people. The Colombian State owns the country effective decent policies beyond DP to have access to the right of housing as a reality for many Colombian people.

The elements mentioned here by the Decree No 008, 2009 represents a significant advanced in the demanding process of the displaced population rights and also to guarantee to be the opening door to the right of housing and decent habitat to every single inhabitant in the whole national territory. The stress in the territorial entities responsibility, especially highlighting POT and the land usage, It is a step forward in the planning and territorial regulation policies guidelines starting from the population as a whole needs which guarantees the necessary boundaries to impact the land, real estate and construction market in the city, region and country model definition for the Colombian case. 


\section{Bibliografía/Bibliography}

ASAMBLEA NACIONAL CONSTITUYENTE. Constitución Política de Colombia. Bogotá: Ed. Impreandes S.A. Presidencia de la República. Bogotá, Colombia. 1991.

CODHES. Desplazamiento forzado y políticas públicas. Comisión de seguimiento a la política pública sobre desplazamiento forzado: Sentencia T-025 - Primer informe. Consultoría para los Derechos Humanos y el Desplazamiento. UNDP. Redes reconciliación y desarrollo. Embajada Británica. Bogotá, Colombia. 2006.

CODHES INFORMA. Víctimas emergentes. Desplazamiento, Derechos Humanos y Conflicto Armado en 2008. Boletín Informativo de la Consultoría para los Derechos Humanos y el Desplazamiento, número 75, Bogotá, 22 de abril de 2009. En línea. 2009. [fecha de consulta: 25 mayo 2009]. Disponible en: <http://www.codhes. org/images/stories/pdf/codhes\%20informa\%20 n\%C2\%BA\%2075\%20act.pdf>

COMISIÓN DE SEGUIMIENTO A LA POLÍTICA PÚBLICA SOBRE EL DESPLAZAMIENTO FORZADO. Encuesta Nacional de Verificación, Bogotá, Colombia. 2008.

CONSEJO ECONÓMICO Y SOCIAL - ONU. Principios Rectores de los desplazamientos internos. Comisión de Derechos Humanos. 54º período de sesiones, New York. 1998. En línea. 2009. [fecha de consulta: 25 mayo 2009].<http://www.acnur.org/biblioteca/ pdf/0022.pdf>
CORTE CONSTITUCIONAL DE COLOMBIA. Sentencia T-025/04. Referencia: expediente T-653010 y acumulados. Acción de tutela, instaurada por Abel Antonio Jaramillo, Adela Polonia Montaño, Agripina María Núñez y otros, contra la Red de Solidaridad Social, el Departamento Administrativo de la Presidencia de la República, el Ministerio de Hacienda y Crédito Público, el Ministerio de Protección Social, el Ministerio de Agricultura, el Ministerio de Educación, el INURBE, el INCORA, el SENA y otros. Bogotá, Colombia. 2004.

CORTE CONSTITUCIONAL DE COLOMBIA. SALA SEGUNDA DE REVISIÓN. AUTO No. 008 de 2009. Referencia: Sentencia T-025 de 2004 - Protección del derecho a la vida y a la seguridad personal de líderes de la población desplazada y personas desplazadas en situación de riesgo. Adopción de medidas de protección de los derechos a la vida y a la seguridad personal de algunos líderes de la población desplazada y ciertas personas desplazadas en situación de riesgo. Bogotá, Colombia. 2009.

DANE. Censo general de Colombia 2005. Departamento Administrativo Nacional de Estadística. Bogotá. Colombia. 2006.

DECRETO 42. Por el cual se otorga facultades al Consejo Nacional de Estupefacientes para la administración y disposición de los bienes vinculados directa o indirectamente o provenientes del narcotráfico. Ministerio de justicia y derecho. Presidencia de la República de Colombia. Bogotá. Colombia. 1990. 
DECRETO 555. Por el cual se crea el Fondo Nacional de Vivienda "Fonvivienda". Presidencia de la República de Colombia. Bogotá. Colombia. 2003.

DNP. Documento CONPES 2484. Consejo Nacional de Política Económica y Social. República de Colombia. Departamento Nacional de Planeación. DNP: UDS - Misión Social. Bogotá. Colombia. 1990.

DNP. Documento CONPES 3305. Lineamientos para optimizar la Política de Desarrollo Urbano. Consejo Nacional de Política Económica y Social. República de Colombia. Departamento Nacional de Planeación. DNP: DDUPA. Ministerio de Ambiente, Vivienda y Desarrollo Territorial. Bogotá. Colombia. 2004.

DNP. Documento CONPES Social 102. Red de protección social contra la extrema pobreza. Consejo Nacional de Política Económica y Social. República de Colombia. Departamento Nacional de Planeación. DNP: DDUPA. Bogotá. Colombia. 2006.

DNP. Documento CONPES Social 40. Focalización del Gasto Social. Consejo Nacional de Política Económica y Social. República de Colombia. Departamento Nacional de Planeación. DNP: DDUPA. Bogotá. Colombia. 1995.

DNP. Plan Nacional de Desarrollo 2002 - 2006. "Hacia un Estado Comunitario", Bogotá, Colombia. 2003.

DNP. Plan Nacional de Desarrollo 2006 - 2010. "Estado Comunitario: desarrollo para todos”, Bogotá, Colombia. 2007.
LEY 387. Ley por la cual se adoptan medidas para la prevención del desplazamiento forzado; la atención, protección, consolidación yestabilización socioeconómica de los desplazados internos por la violencia en la República de Colombia. Congreso de la República. Bogotá, Colombia. 1997.

LEY 388. Ley de Desarrollo Territorial. La Política del Salto Social. Ministerio de Desarrollo Económico. Viceministerio de Vivienda, Desarrollo Urbano y Agua Potable. Congreso de la República. Bogotá, Colombia. 1997.

LEY 160. Por la cual se crea el Sistema Nacional de Reforma Agraria y Desarrollo Rural Campesino, se establece un subsidio para la adquisición de tierras, se reforma el Instituto Colombiano de la Reforma Agraria y se dictan otras disposiciones. Congreso de la República. Bogotá, Colombia. 1994.

LOZANO E., IGNACIO; RAMOS F., JORGE. Análisis sobre la incidencia del impuesto del 2x1000 a las transacciones financieras. Manuscrito, Bogotá. En línea. 2000. [fecha de consulta: 25 abril 2008]. Disponible en: < http://www.banrep.gov.co/ docum/ftp/borra143.pdf >

MONTEIRO, TERESINHA. Et al. Gota a gota. Desplazamiento Forzado en Bogotá y Soacha. CODHES - Fundación de Atención al Migrante (FAMIG). Bogotá, Colombia. 2007.

PRADILLA COBOS, EMILIO. Neoliberalismo, globalización, regiones y ciudades en crisis. En: Cemos Memoria No.169 septiembre de 2002. México. En línea. 2000 [fecha de consulta: 21 septiembre 2008]. Disponible en: <http://www. memoria.com.mx/169/pradilla.htm P2.> 
ROMERO, MARCO. Los límites de la política pública frente al desplazamiento forzado. En: Desplazamiento forzado y políticas públicas. CODHES. Bogotá, Colombia. 2006.

ROMER0, MARC0. Desplazamiento forzado: entre la guerra y le economía política del despojo. CODHES. Universidad Nacional de Colombia. Bogotá, Colombia. 2007.

RUIZ RUIZ, NUBIA YANETH. El Desplazamiento Forzado en el Interior de Colombia: Características sociodemográficas y pautas de redistribución territorial 2002 - 2004. Tesis Programa de Doctorado en Demografía Universidad Autónoma de Barcelona. Departamento de Geografía Centro de Estudios Demográficos. Barcelona, España. 2008.

TORRES TOVAR, CARLOS ALBERTO. "La vivienda de la población desplazada en Colombia. Un derecho vulnerado que demanda reparación". Proceso nacional de verificación a la sentencia T-025 de 2004. CODHES. Mesa de expertos - derecho a la vivienda. Bogotá, Colombia. 2008. 